$2 / 2 / 82+1175$

\title{
A MODEL OF PENETRATION OF COAL BOILERS AND COGENERATION IN THE PAPER INDUSTRY
}

\author{
David B. Reister
}

ORAU/IEA--882-I (M)

DE82. 010027

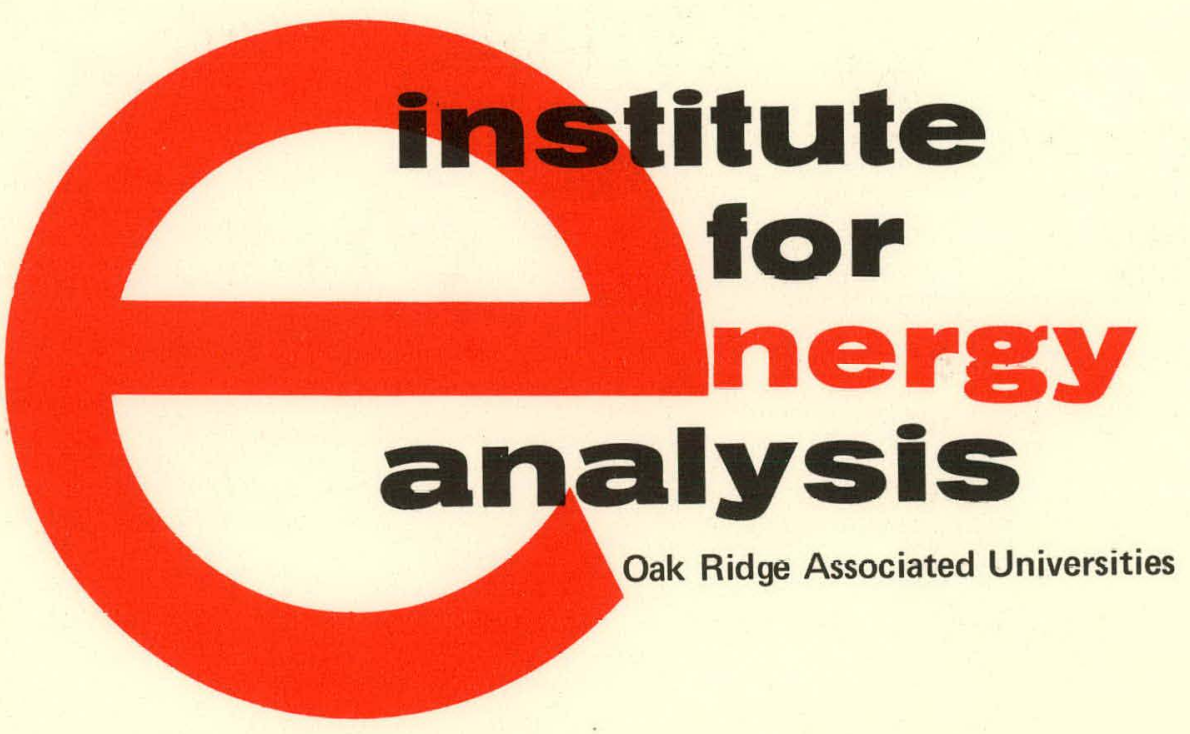




\section{DISCLAIMER}

This report was prepared as an account of work sponsored by an agency of the United States Government. Neither the United States Government nor any agency Thereof, nor any of their employees, makes any warranty, express or implied, or assumes any legal liability or responsibility for the accuracy, completeness, or usefulness of any information, apparatus, product, or process disclosed, or represents that its use would not infringe privately owned rights. Reference herein to any specific commercial product, process, or service by trade name, trademark, manufacturer, or otherwise does not necessarily constitute or imply its endorsement, recommendation, or favoring by the United States Government or any agency thereof. The views and opinions of authors expressed herein do not necessarily state or reflect those of the United States Government or any agency thereof. 


\section{DISCLAIMER}

Portions of this document may be illegible in electronic image products. Images are produced from the best available original document. 
Oak Ridge Associated Universities is a private, not-for-profit association of more than 50 colleges and universities. It seeks to help the U.S. Department of Energy, other private and governmental organizations, and its member institutions solve societal problems relating to energy, health, and the environment. Established in 1946, Oak Ridge Associated Universities was one of the first university-based, science-related corporate management groups. Today it conducts diverse, cooperative programs of research, training, education, and information and is noted for its contributions to the development of science and human resources.

The Institute for Energy Analysis was established in 1974 as a division of Oak Ridge Associated Universities to examine broad questions of energy policy. More specifically, it assesses energy policy and energy research and development options and analyzes alternative energy supply and demand projections from technical, economic, and social perspectives. The Institute focuses primarily on national energy issues, but it is also concerned with regional and international energy questions and their implications for solution of domestic energy problems.

\section{NOTICES}

The opinions expressed herein do not necessarily reflect the opinions of the sponsoring institutions of Oak Ridge Associated Universities.

This report was prepared as an account of work sponsored by an agency of the United States Government. Neither the United States Government nor any agency thereof, nor any of their employees, makes any warranty, express or implied, nor assumes any legal liability or responsibility for any third party's use or the results of such use of any information, apparatus, product or process disclosed in this report, nor represents that its use by such third party would not infringe privately owned rights.

Available from the National Technical Information Service, U.S. Department of Commerce, Springfield, Virginia 22161. Please direct all price inquiries to NTIS. 
ORAU/IEA 82-1(M)

Research Memorandum

\title{
A MODEL OF PENETRATION OF COAL BOILERS AND COGENERATION IN THE PAPER INDUSTRY
}

David B. Reister

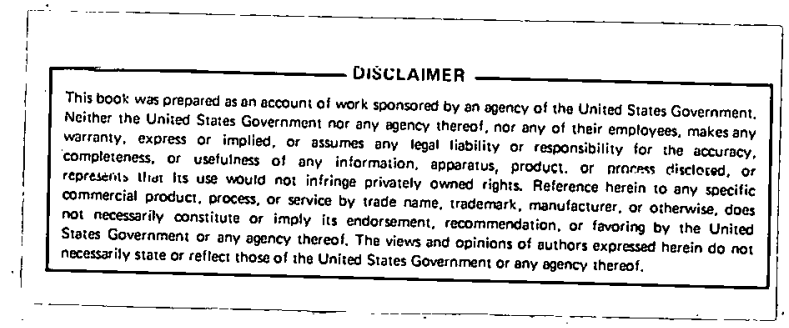

\author{
January 1982 \\ Institute for Energy Analysis \\ Oak Ridge Associated Universities \\ Oak Ridge, Tennessee 37830
}

Research memorandums document substantive work in progress and receive internal review.

This report is based on work performed under contract number DE-AC05-760R00033 between the U.S. Department of Energy, Office of Technology Impacts, and Oak Ridge Associated Universities. 
THIS PAGE

\section{WAS INTENTIONALLY LEFT BLANK}




\begin{tabular}{|c|c|}
\hline & Page \\
\hline CHAPTER 1. INTRODUCTION & 1 \\
\hline CHAPTER 2. THE PENETRATION MODEL & 9 \\
\hline The Operation Module & 15 \\
\hline The 011/Gas Fuel Share Module & 18 \\
\hline The Investment Module & 19 \\
\hline The Cost Module & 23 \\
\hline The Bofler Technology Module & 25 \\
\hline The Boller Stock Module & 29 \\
\hline The Capital Price Module & 30 \\
\hline Analysis of Policy Alternatives & 31 \\
\hline CHAPTER 3. RESULTS OF THE PENETRATION MODEL & 33 \\
\hline CHAPTEK 4. CONCLUSIONS & 47 \\
\hline DATA APPENDIX & 51 \\
\hline REFERENCES & 83 \\
\hline
\end{tabular}


THIS PAGE

\section{WAS INTENTIONALLY \\ LEFT BLANK}




\section{TABLES}

Page

Table 1. Total Purchased Fuel per Ton of Paper 5

Table 2. Purchased Fuel Shares in the Paper Industry (\%) 5

Table 3. Price of Purchased Fuel in the Paper Industry

$\left(1971 \$ / 10^{6} \mathrm{Btu}\right) \quad 6$

Table 4. Cogeneration in the Paper Industry 8

Table 5. Boiler Options in the Penetration Model 12

Table 6. Coefficients for the Investment Distribution Function 22

Table 7. Factors of Production for the Bofler Options 24

Table A-1. Estimated Fuel and Electricity Demand by the
Papermill Industry

Table A-2. Estimated Fuel and Electricity Demand by the. Paper

Industry 56

Table A-3. Demand for Purchased Fuel by the Paper Industry:

Comparison of Data from the Bureau of the Census and

the American Paper Institute

Table A-4. Consumption of Fuel and Production of Energy Service by Botlers in the Papermill Industry

Table A-5. Consumption of Fuel, Coverage Factor, and Capacity Factors from the Major Fuel Burning Installation (MFBI)

Data Base

Table A-6. Consumption of Fuel in 1974 and Full Capacity Hours

Table A-7. Capacity for Coal Bollers by Year of Installation and Throttle Conditions

Table A-8. Capac1ty for Fuel 011 and Natural Gas Bollers 64

Table A-9. Capacity for Other (Bark and Spent Liquor) Boilers 65

Table A-10. Capacity by Fuel Type and Throttle Conditions for Bollers Ordered from 1965 to 1977 


\section{TABLES}

$\ddot{\text { Page }}$

Table A-11. Comparison of MFBI and ABMA Estimates of Capacity by Fuel Type and Throttle Conditions

Table A-12. Results of the Major Boller Model for a Recovery: Boiler and a Combination Boller

Table A-13. Base Year (1976) Accounts by Fuel Type and Throttle Conditions

Table A-14. Total Capacity, Tntal Production of Prucess Sceam, and Full Capacity Hours for 1972, 1975, 1976, and $1977 \quad 75$

Table A-15. Annual Electricity and Steam Balance for the Papermill Industry

Table A-16. Input-Output Coeffictents for the Bo1ler Options Where Output is $10^{9}$ Pounds of Process Steam 


\section{FIGURES}

Page

Figure 1. The Structure of the Energy Demand Model of the Paper Industry

Figure 2. The Penetration Model . 11

Flgure 3. Structure of the Penetration Model 13

Figure 4. The Operation Module 16

Figure 5. The Energy Balance Module 18

F1gure 6. The Investment Module 19

Figure 7. The Cost Module 23

Figure 8. The Botler Technology Module 25

Figure 9. The Major Boller Model 26

Figure 10. The Boller Stock Module 29

F1gure 11. The Capital Price Module 30

Figure 12. The Price Index for $011 /$ Gas Service for Three

Figure 13. Demand for 011/Gas Service 35

Figure 14. Demand for Coal Service 35

Figure 15. Capacity by Year of Installation of Type A Coal Bollers 41

Figure 16. Total Capacity of Type A Coal Botlers 41

F1gure 17. Capacity by Year of Installation of Type D Boilers 42

F1gure 18. Total Capacity of Type D Coal Boflers 42

Figure 19. Capacity by Year of Installation of Type A 011/Gas
Boflers

Figure 20. Total Capacity of Type A 011/Gas Bollers 43

Figure 21. Capacity by Year of Installation of Type C 011/Gas Bollers 44 


\section{FIGURES}

$\underline{\text { Page }}$

Figure 22. Total Capacity of Type C 011/Gas Boilers 44

Figure 23. Purchased Electricity 45

F1gure 24. Generated Electric1ty 45

F1.gure 25. Power Rat1o 46

F1gure A-1. Smooth MFBI Data for Type D Coal Botlers , 67 


\begin{abstract}
A MODEL OF PENETRATION OF COAL BOILERS
AND COGENERATION IN THE PAPER INDUSTRY
\end{abstract}

\begin{abstract}
A model has been developed to forecast the penetration of coal bollers and cogeneration of electricity in the paper industry. Given the demand for energy services (process steam and electricity) by the paper industry, the Penetration Model forecasts the demand for purchased fuel and electric1ty. The model splits the demand for energy service between energy carriers (coal, fuel oil/natural gas, bark, and spent liquor) on the basis of the Installed capacity of 16 types of boilers (combinations of four types of energy carriers and four types of throttle conditions). Investment in new boilers is allocated by an empirical distribution function among the 16 types of bollers on the basis of life cycle cost.

In the short run (5 years), the Penetration Model has a small price response. The model has a large price response in the long run ( 30 years). For constant fuel prices, the model forecasts a 19 -percent share for coal and a 65-percent share for residual ofl in the year 2000 . If the real price of oil and gas doubles by the year 2000 , the model forecasts a 68-percent share for coal and a 26-percent share for residual ofl.
\end{abstract}




\section{CHAPTER 1}

INTRODUCTION

This report describes a model to forecast the penetration of coal bollers and cogeneration of electricity in the paper 1ndustry. This project 1s part of a program in the Energy Conservation Section of the Energy Division of Oak Ridge National Laboratory (ORNL) to develop economic-engineering energy demand models for the residential, commercial, and Industrial sectors. The industrial modeling program has developed three models: the Phase I Model, the Penetration Model, and the Oak Ridge Industrial Model (ORIM).

Development of the Phase I Model began in the middle of the $1977 \mathrm{fis}-$ cal year and was completed in the 1978 fiscal year. The Phase I Model was described in a previous report (1). Development of the Penetration Model began in the middie of the 1978 fiscal year and was completed in the first half of the 1979 fiscal year. Thls report was written in February 1979, but the ORNL requirement that all reports use the International system of Units (SI) delayed its pubilcation for two years. (At the request of the sponsors, conventional English units are used throughout this report.) Development of ORIM began in the 1979 fiscal year and was completed in the 1980 fiscal year. ORIM was described in a five-volume report (2). Since its development, ORIM has gained widespread acceptance as an important tool to analyze the impact of prices and policies on energy demand. After its development, the Penetration Model was delivered to its 
sponsors and has not been used very much. However, many of the features of ORIM were first used in the Penetration Model. As an introduction to the Penetration Model, it is interesting to contrast its features with those of ORIM.

Both models are based on the concept of energy service. However, the scope of the Penetration Model is much more narrow thall the scope of ORIM. The Penetration Model simulates the provision of one energy service (steam) to one industry (paper). ORIM simulates the provision of four energy services (process steam, process heat, machine drive, and electrical services) to nine industries in ten regions.

Conceptually, energy demand is determined by the equation

$$
\text { Energy demand }=\frac{\text { Energy }}{\text { Service }} \cdot \frac{\text { Service }}{\text { Output }} \cdot \text { Output } .
$$

We shall call a model that forecasts the ratio of energy and service a fuel share'model. We shall call a model that forecasts the ratio of service and output a conservation model. The Phase I Model is a complete model of energy demand In the paper Industry; the Phase I Model 1.8 a comb1nation of a fuel share model, a conservation model, and a model that forecasts output by the paper industry. The Penteracion Model is a fuel share model that is designed to replace the fuel share model in the Phase I Model. ORIM is both a fuel share model and a conservation model; it requires an exogenous forecast of industrial output. 
ORIM divides the market for process steam into 24 submarkets based on size, capacity factor, coal feasibility, cogeneration, and fuel; for each variable there are two options. The Penetration Model divides the market into 16 submarkets based on cogeneration and fuel. The submarkets for the Penetration Model are determined by only two factors, but there are four options for each of the two factors; there are four sets of cogeneration options and four types of fuel (spent liquor, bark, coal, and oil/gas). The Penetration Model does not distinguish submarkets on the basis of size and capacity factor; in the ORIM data base, 64 percent of the bollers in the paper industry are large with a high capacity factor, and 36 percent of the bollers are small. Since all of the boilers in the Penetration Model are large with a high capacity factor, the model simulates the biggest market but does not capture a significant portion of the market.

In both the ORIM and the Penetration Model there are two types of purchased-fuel boilers: oll/gas boilers, which can burn etther fuel oil or natural gas, and coal bollers. In ORIM all types of fuel can be consumed in elther type of boiler. In the Penetration Model all coal boilers burn exclusively coal, and oil/gas bollers never burn coal. If coal is signif1cantly less expensive than fuel ofl or natural gas, both models w1ll give similar results. However, if coal is about the same price as natural gas or fuel ofl, ORIM will forecast that coal bollers will burn both coal and gas or oil.

Both models simulate investment decisions and keep track of vintages of capital stock. ORIM makes investment decisions every 5 years, while the 
Penetration Model makes annual decisions. There are many other features of the two models that are simflar; these will be noted in the report.

At the same time that the Penetration Model was belng developed, Jackson and Kaserman of Oak Ridge National Laboratory were developing a penetration model for use in the residential and commercial sectors (3). Their model is quite different from the Penetration Model. They assume a 100-percent market share for the new invention and attempt to model the premature retirement decision. We allow for premature retirement but. assume that most retirement occurs after 30 years. Our primary focus is allocating investment among the 16 types of bollers. Thus, the two approaches are complementary and focus on two different aspects of the same phenomenon.

To conclude the introduction, we will briefly review historical patterns of energy demand and cogeneration. Historical demand patterns for purchased fuel are shown in Tables 1 and 2. Demand for purchased fuel by the paper industry doubled between 1954 and 1971 and has remained relatively constant since 1971 (Table 1). Similarly, the production of paper doubled between 1954 and 1971, and has remalned relatively constant since 1971. The demand for purchased fuel per ton of paper, the fuel ratio, has been relatively constant with a gradual decrease. The average annual decrease in the fuel ratio from 1954 to 1977 was -0.8 percent, while the rate of decrease from 1958 to 19.77 was -1.6 percent.

Table 2 shows that in 1954 coal was the dominant purchased fuel; by: 1971 fuel ofl and natural gas had the dominant role, and the coal share had 
TABLE 1. TOTAL PURCHASED FUEL PER TON OF PAPER ${ }^{a}$

\begin{tabular}{ccc}
$\begin{array}{c}\text { Purchased } \\
\text { Fuel }\end{array}$ & $\begin{array}{c}\text { Paper } \\
\text { Production } \\
\left(10^{12} \text { Btu }\right)\end{array}$ & $\begin{array}{c}\text { Fuel } \\
\text { Ratio }\end{array}$ \\
\hline
\end{tabular}

$\begin{array}{lrrr}1954^{\circ} & 568 & 26.876 & 21.15 \\ 1958 & 731 & 30.823 & 23.70 \\ 1962 & 838 & 37.543 & 22.32 \\ 1967 & 936 & 46.926 & 19.94 \\ 1971 & 1119 & 55.092 & 20.31 \\ 1972 & 1173 & 59.457 & 19.73 \\ 1975 & 975 & 52.359 & 18.63 \\ 1976 & 1045 & 60.043 & 17.40 \\ 1977 & 1068 & 60.736 & 17.58\end{array}$

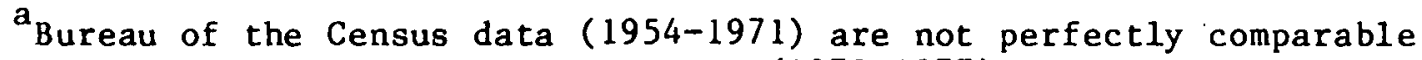
with American Paper Institute data (1972-1977).

TABLE 2. PURCHASED FUEL SHARES IN THE PAPER INDUSTRY (\%) ${ }^{a}$

Fuel $011 \quad$ Natural Gas Coal

\begin{tabular}{crrr}
\hline & & \\
1954 & 25 & 21 & 54 \\
1958 & 22 & 30 & 49 \\
1962 & 23 & 32 & 44 \\
1967 & 28 & 39 & 34 \\
1971 & 36 & 44 & 21 \\
1972 & 42 & 39 & 19 \\
1975 & 47 & 36 & 18 \\
1976 & 48 & 31 & 20 \\
1977 & 49 & 30 & 21 \\
& & & \\
\hline & & & \\
a Bureau of the Census data (1954-1971) are not perfectly comparable \\
with American Paper Institute data (1972-1977).
\end{tabular}


decreased by more than a factor of two. From 1971 to 1977 the coal share has been constant, the gas share has decreased, and the ofl share has Increased.

Can we explain these changes in fuel share? One of the primary factors that determines fuel shares is fuel price. Table 3 presents data on average fuel prices for several years. The prices have been corrected for inflation and are expressed in 1971 dollars.

TABLE 3. PRICE OF PURCHASED FUEL IN THE PAPER INDUSTRY

$$
\left(1971 \$ / 10^{6}\right. \text { Btu) }
$$

\begin{tabular}{lcccc} 
& Distillate 011 & Residual 011 & Coal & Natural Gas \\
\hline & & & & \\
1962 & 0.76 & 0.54 & 0.44 & 0.41 \\
1967 & 0.53 & 0.44 & 0.39 & 0.37 \\
1971 & 0.64 & 0.55 & 0.48 & 0.38 \\
1974 & 1.48 & 1.37 & 0.87 & 0.55 \\
1975 & 1.53 & 1.35 & 1.03 & 0.74 \\
1976 & 1.51 & 1.28 & 0.91 & 0.93
\end{tabular}

Source: Bureau of the Census. (4).

For all years, except 1976, the price of natural gas 1s lower than coal. For all years distillate fuel ofl is more expensive than residual fuel ofl, which is more expenstve than coal.

Fuel price is an important factor, but it is not the best explanation for changes in fuel shares. The best explanation is provided by the cost of energy service. In the data appendix, we will develop estimates of the 
total cost of energy service, but we do not have a historical time series as given in Table 3. We can develop qualitative estimates of the cost of energy service.

Natural gas is a clean-burning premium fuel, while coal is a dirty fuel that requires storage space, handling equipment, and environmental protection equipment. Fuel o1l is a much cleaner fuel than coal; it requires storage tanks but no special handling equipment. The fuel cholce Is based on the total cost of energy service, which Includes the fuel cost plus the cost of capital and labor. The cost of capital and labor for coal bollers is much higher than the cost for fuel oil bollers, which is slightly higher than the cost for natural gas bollers. From 1945 to 1981 the total cost of energy service from oll and gas bollers has been less than the total cost from coal bollers.

The lower cost for ofl/gas bollers has been the primary factor responsible for the loss of market share by coal boilers. From 1971 to 1977 natural gas lost a substantial portion of 1 ts market share to fuel ofl bollers despite the fact that the price of natural gas service was lower than the price of fuel ofl service. How can we explain this counterintultive result? Clearly, the loss of market share has been caused by natural gas curtailments and not by market forces.

Table 4 displays historical data on electricity generated by the paper 1ndustry and on paper production. The amount of electricity generated per ton of paper has been remarkably constant; there was a slight Increase in the early 1960s, followed by a gradual decline. 
TABLE 4. COGENERATION IN THE PAPER INDUSTRY

Generated Electricity

$\left(10^{9} \mathrm{kWh}\right)$
Paper Production $\left(10^{6}\right.$ Ton)
Generation Ratio (kWh/Ton)

$\begin{array}{ll}1954 & 12.6870 \\ 1958 & 16.9780 \\ 1962 & 21.1650 \\ 1967 & 23.2114 \\ 1971 & 25.3843 \\ 1972 & 27.5627 \\ 1975 & 24.4326 \\ 1976 & 25.4902 \\ 1977 & 27.3835\end{array}$

26.876

30.823

37.543

49.926

55.092

59.457

52.359

60.043

60.736
472

551

564

495

461

464

467

425

451

Source: Bureau of the Census (4).

To summarize, the historical data shows the following:

1. a gradual decline in purchased fuel per ton of paper;

2. a loss of market share by coal;

3. the market shares for fuel ofl and natural gas change rapid1y without any impact on the market share for coal; and

4. the amount of electricity generated per ton of paper has been almost constant. 
CHAPTER 2

THE PENETRATION MODEL

This chapter begins with a brlef revlew of the Phase I Model for the paper Industry (1). Using the framework of the Phase I Model, the Inputs and outputs of the Penetration Model are defined. The chapter concludes with a discussion of the features of the Penetration Model.

The structure of the Phase I Model is shown in Figure 1. The four submodels of the model are the Paper Demand Submodel, the Pulp and Paper Process Submodel, the Fuel Share Submodel, and the Energy Conversion Submodel.

Given exogenous information on paper product prices, population, disposable income, and gross national product, the Paper Demand Submodel forecasts the demand for 11 types of paper products.

The Pulp and Paper Process Submodel simulates the production of 11 types of paper products using 45 process vectors. The mix of the 45 process vectors to produce the 11 types of paper products is an exogenous input to the model, rather than the result of cost optimization. The output of the process model is the demand for steam and electricity and the supply of bark and spent 1iquor. To introduce conservation and other forms of technological change, the output of the process model is multiplied by adjustment factors to produce the final output forecast.

Given fuel prices, the Fuel Share Submodel forecasts the share of the purchased fuel that w1ll be captured by each type of fuel. Given the 


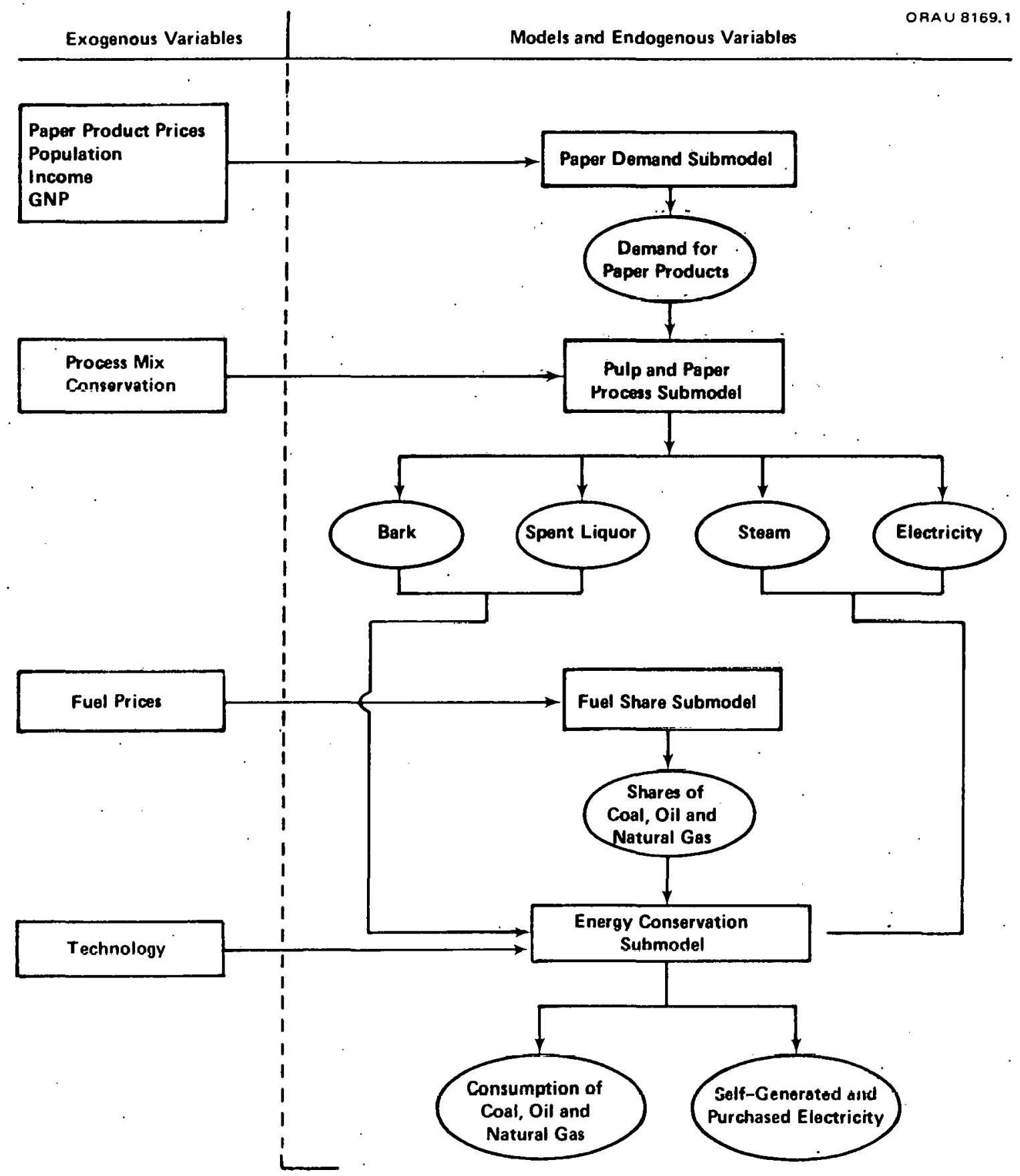

Figure 1. The Structure of the Energy Demand Model of the Paper Industry 
demand for steam and electriclty, the supply of bark and spent 11quor, the fuel shares, and exogenous technology assumptions on energy conversion efficlencles and the amount of self-generated electricity per unit of process steam, the energy conversion submodel forecasts the demand for purchased fuel and purchased electricity.

The Penetration Model (Figure 2) replaces the Fuel Share Submodel and the Energy Conversion Submodel. The Penetration Model simulates the provision of energy services (steam and electricity) to the paper industry and requires information on the supply of bark and spent 1iquor. (In this report, bark includes both bark and hogged fuel as reported by the American Paper Institute.) The primary output of the Penetration Model is the demand for purchased fuel and purchased electrictiy.

ORAU 8169.2

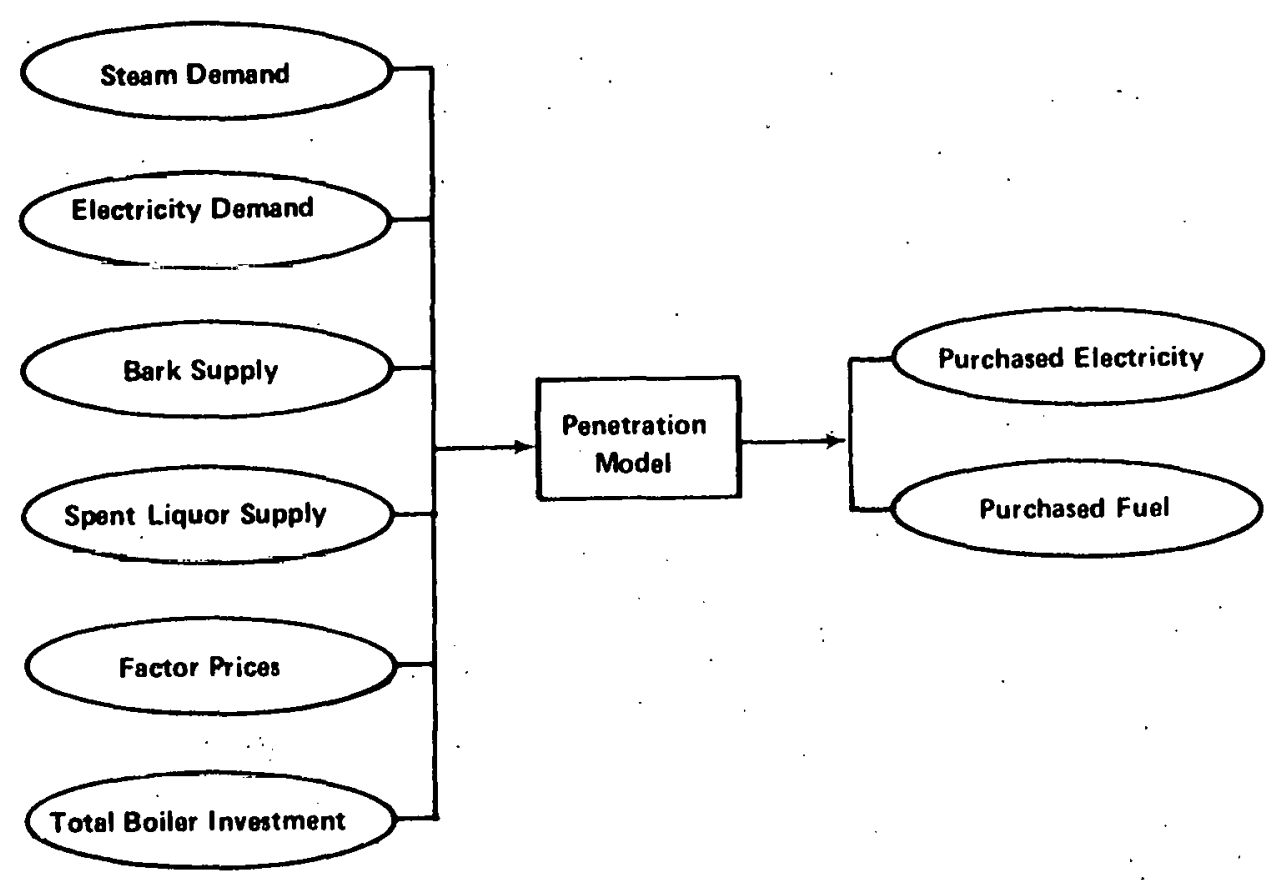

Figuro 2. The Penetration Model 
Comparison of Figures 1 and 2 reveals that the Penetration Model has two exogenous inputs that the Phase I Model does not have: factor prices and total boller investment. In the Phase I Model, the fuel shares werre determined by fuel prices. In the Penetration Model, the fuel shares are determined by all of the prices of the factors of production required to produce energy services; these factors include fuel, operations and matntenance, and capital.

The Penetration Model forecasts the penetration rate for the 16 types of bollers shown in Table 5. The boller options include four types of fuel (spent 1iquor, bark, coal, and ofl/gas) and four throttle conditions (combinations of temperature and pressure of the steam output from the boilers) for a total of 16 types of boilers.

TABLE 5. BOILER OPTIONS IN THE PENETRATION MODEL COGENERATION OPTIONS

\begin{tabular}{lcccc}
\hline Throttle conditions & A & B & C & D \\
Eressure (psia) & 200 & 615 & 915 & 1265 \\
Temperature $\left({ }^{\circ} \mathrm{F}\right)$ & 450 & 750 & 825 & 900 \\
Fuel & & & & \\
Spent liquor & 1 & 2 & 3 & 4 \\
Bark & 5 & 6 & 7 & 8 \\
Coal & 9 & 10 & 11 & 12 \\
Oil/gas & 13 & 14 & 15 & 16 \\
\hline
\end{tabular}


A fundamental assumption in the Penetration Model is that o1l/gas botlers (which burn restdual fuel o11, distillate fuel oil, and natural gas) cannot burn coal. A second fundamental assumption is that coal will be less expensive than ofl/gas, while coal bollers are more expensive than oll/gas bollers. Thus, the demand for coal is controlled by the stock of coal bollers.

Given the total boiler Investment for each year, subdivided into spent liquor bollers, bark bollers, and purchased-fuel bollers, the Penetration Model allocates the investment in new boilers among the 16 types of bollers shown in Table 5 .

The Penetration Model can be subdivided Into the five modules shown in Figure 3. The input-output $(I-0)$ structure of each of these modules will be discussed in the following paragraphs. The Penetration Model requires a substantial data base. Most of the research effort has been devoted to data base preparation. This task has been divided into the three modules

DATA BAEE PREPARATION

\begin{tabular}{|c|}
\hline Boiler Technology Module \\
\hline Boiler Stock Module \\
\hline Capital Price Module \\
\hline
\end{tabular}

PENETRATION MODEL

\begin{tabular}{|c|}
\hline Operation Module \\
\hline Energy Balance Module \\
\hline Oil/Gas Fuel Share Module \\
\hline Investment Module \\
\hline Cost Module \\
\hline
\end{tabular}

Figure 3. Structure of the Penetration Model 
shown in Figure 3. The input-output structure of these modules will be discussed after the discussion of the Penetration Model modules.

Consider the operation of the Penetration Model in the base year. The stocks of the 16 types of bollers are fixed at the levels estimated by the Boiler Stock Module. Since there is no new Investment, no penetration of new technology w11l take place. Even though no new investment can occur, the first five factors on the left side of Figure 2 can influence the demand for purchased electricity and fuel. If all other exogenous factors were constant and steam demand fell, the demand for purchased fuel would drop, the generation of electricity would drop, and the demand for purchased electricity would increase.

As an introduction to the structure of the model, the 1mpact of a drop in demand for steam w1ll be traced through the varfous parts of the model. We begin with the Boiler Technology Module. Each of the 16 types of bollers is described by fixed input-output coefficients, which are deterint ned by this module. None of the exogenous variables on the left side of Figure 2 have an impact on these coefficients. The output of each type of boller is steam and electricity; the inputs are various types of fuel. A drop in the demand for steam must be allocated among the various types of boilers; this allocation occurs in the Operation Module.

In the Operation Module, a drop in the demand for steam does not result in a unfform reduction of steam from all types of bollers; all of the drop In steam is allocated to the bollers that burn purchased fuel. The allocation among the elght types of purchased-fuel bollers is 
influenced by changes in operating cost. The operating cost, which is determined in the Cost. Module as the product of the boiler I 0 coefficlents and the factor prices, is not influenced by any of the exogenous variables on the left side of Figure 2, except factor prices. Thus, the operating costs are not changed by a drop in the demand for steam, and the drop would be allocated uniformly to all types of purchased-fuel bollers.

A decrease in the production of steam results in a proportional drop In the demand for purchased fuel and in the generation of electricity. The Energy Balance Module determines the drop in demand for purchased fuel and the increase in demand for purchased electricity. Having completed a brief introduction to the structure of the model, we proceed to a more detalled discussion of each of the modules.

THE OPERATION MODULE

The structure of the Operation Module is shown in Figure 4. Its output is the amount of process steam produced by each type of boller, which 1s expressed by the following equation:

$$
x_{j}(k)=h_{j k} \cdot z_{j}(k)
$$

where $Z_{j}(k)$ is the total stock of boilers of type $j$, in year $k$, measured in $10^{6} \mathrm{lb} / \mathrm{hr}$ of high-pressure steam; $h_{j k}$ is the capacity factor measured In $1000 \mathrm{hr} /$ year; and $x_{j}(k)$ is the process steam output measured in $10^{9}$ 1b/year. The Operation Module determines the capacity factor based on Input of the boller stock and the following exogenous inputs: 
1. total demand for steam,

2. the operating cost of each type of boller,

3. the nominal capacity factor for each type of boiler,

4. the input-output coefficients for each type of boiler, and

5. the supply of bark and spent liquor.

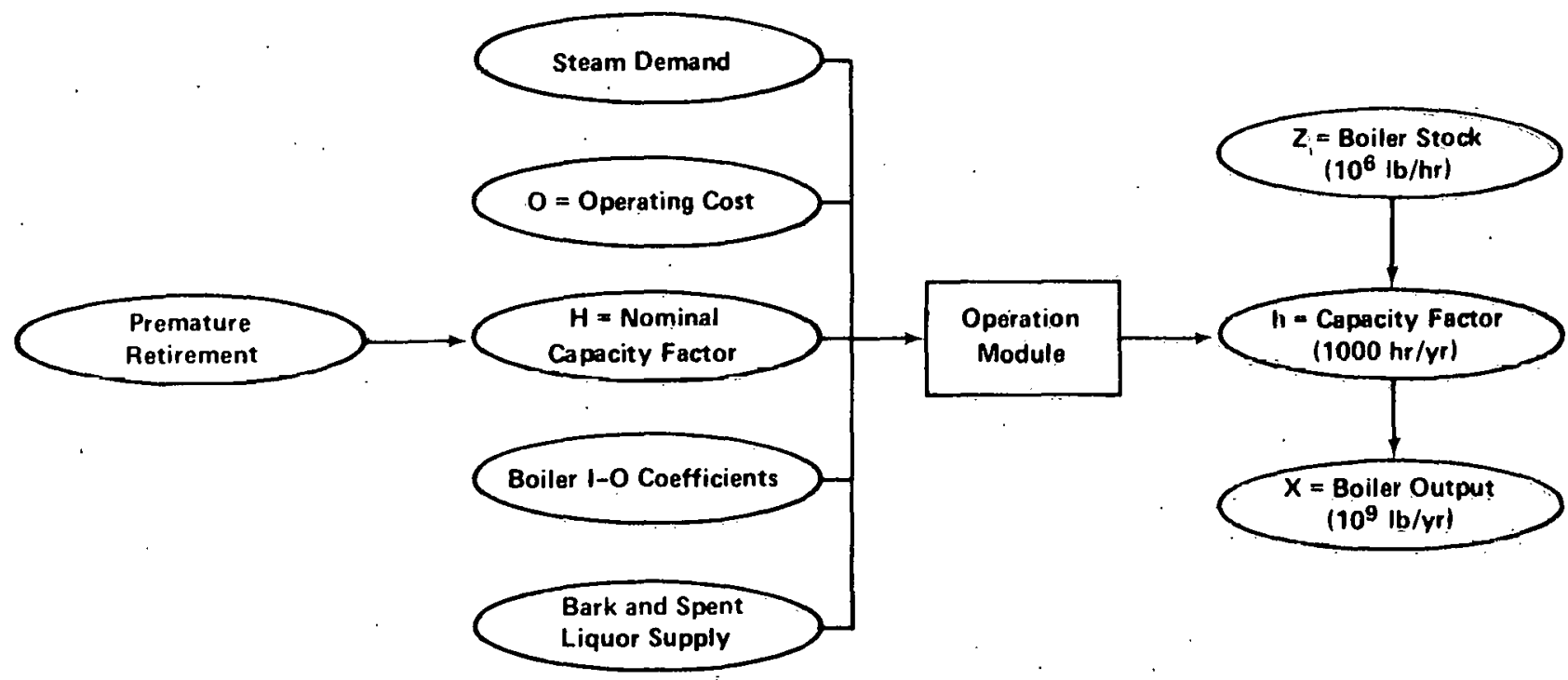

Figure 4. The Operetion Module

1 The nominal capacity factors are the actual capacity factors for the base year, 1976. The operating cost influences the capacity factor; as the relative price of operating a particular type of botler tincrease, its capacity factor decreases. The capacity factors for the spent liquor and bark bollers are adjusted to consume the total supply of bark and spent 
11quor. The total steam demand less the process steam supplied by bark and spent liquor bollers is equal to the steam supply from coal and oil/gas bollers. The output from each type of coal and oil/gas boller is determined by the nominal capacity factors, the operating costs, and the total amount of steam to be supplied by a11 of the o.tl/gas and coal botlers.

Mathematically, the forecast capacity factors $\left(h_{j k}\right)$ are linked to the nominal capacity factors $\left(H_{j}\right)$ by a distribution function, that is

$$
h_{j k}=n\left(O_{j k} / \alpha_{j}\right)^{\mu_{H}}
$$

where $n$ is a normalization factor to match the exogenous supply of bark and spent liquor and the exogenous demand for steam; $0_{j k}$ is the operating cost of boller type $j$ in the year $k$; the coefficlents $\alpha_{j}$ are equal to the operating costs in the base year; and the parameter $\mu$ controls the elasticity of the response to changes in operating cost. The results of this paper are based on an elasticity of $\mu=-0.3$; for this elastictty; a $10-$ percent price increase causes a 3-percent decrease in level of operation. The operating cost is included in Equation 2 to simulate premature retirement for bollers with high operating costs. Equation 2 is an ad hoc creation without a theoretical basis. In ORIM no attempt was made to simulate premature retirement. No attempt was made in either the Penetration Model or ORIM to use the premature retirement model of Jackson and Kaserman (3). 
As an additional method to simulate premature retirement of bollers, the nominal capacity factor for each type of ofl/gas boller is decreased by 5 percent for each year in which the operating cost of the ofl/gas boiler Is greater than the total cost (capital plus operating cost) for a coal boller with the same throttle conditions. Thus, output from ofl/gas boilers can be decreased by higher operating costs through Equation 2 and also through reduction of the nominal capacity factor.

THE OIL/GAS FUEL SHARE MODULE

01l/gas bollers can burn fuel ofl or natural gas, but they cannot burn coal. Given the steam production from each of the four types of ofl/gas boilers, the Energy Balance Module determines the total demand for oll/gas service. Given the demand for ofl/gas service and the relative prices of each type of oil/gas, the 0il/Gas Fuel Share Module (shown in Figure 5)

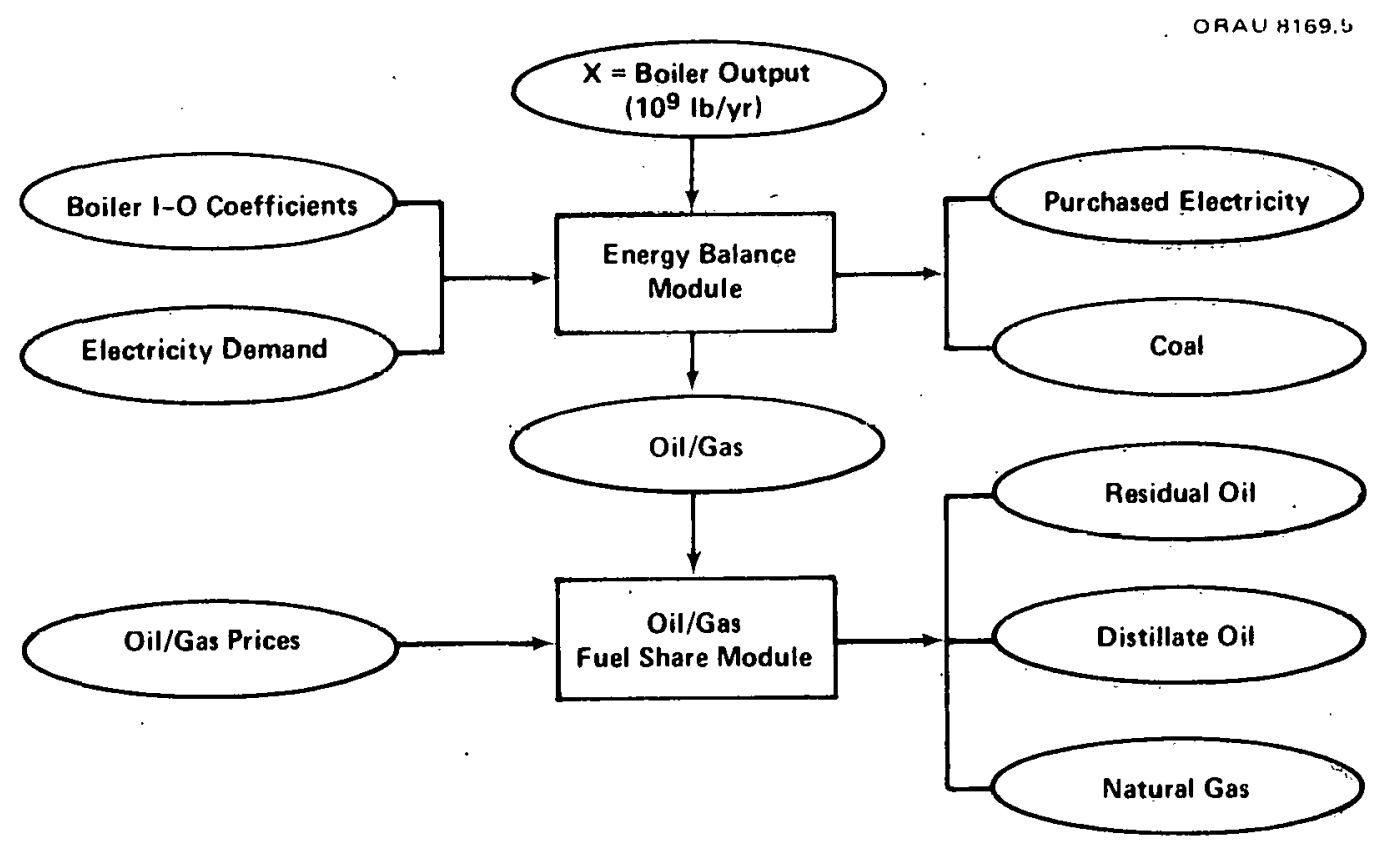

Figure 5. The Energy Balance Module 
determines the demand for residual fuel ofl, distillate fuel ofl, and natural gas.

Existing oil/gas bollers can easily switch from one type of oil/gas to another. Consequently, the Penetration Model can forecast the total demand for oll/gas with greater precision than it can forecast the share for each type of o1l/gas. The 011/Gas Fuel Share Module is baslcally an output section of the model designed to produce a result that is inherently imprecise.

THE INVESTMENT MODULE

The Investment Module is shown in Figure 6. For each year, the inputs to the module are the total number of new spent 11quor bollers, new bark bollers, new purchased-fuel bollers, and the life cycle cost for each bofler option. The output from the module is the amount of new investment In each of the 16 types of boilers. Thus, based on life cycle cost the

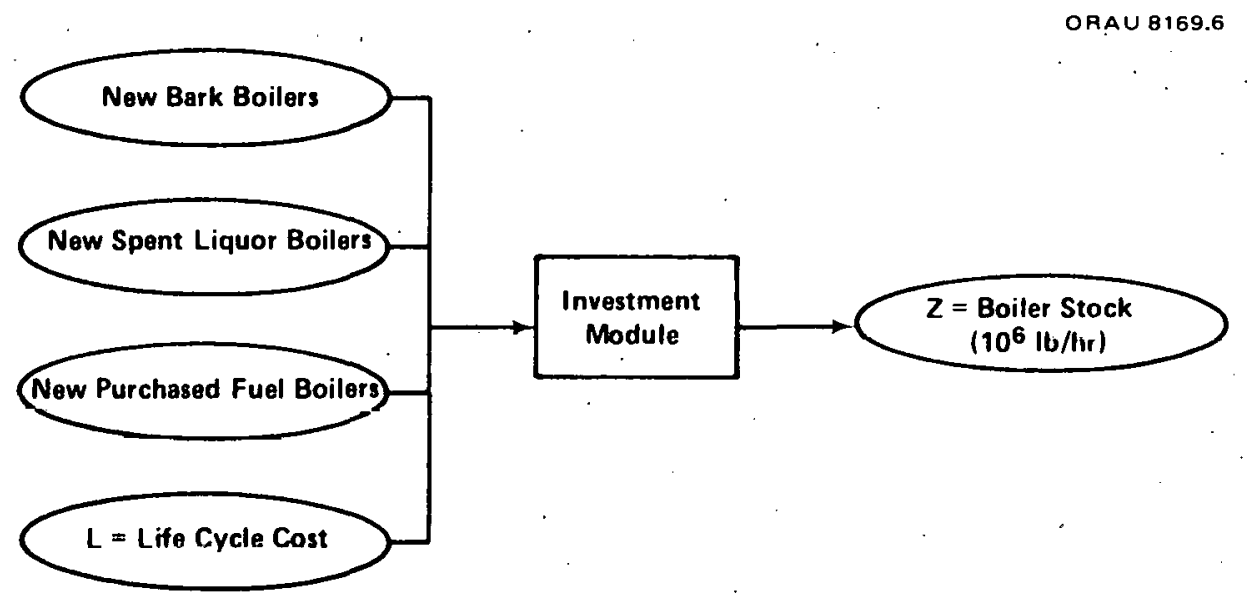

Figure 6. The Investment Module 
Investment Module chooses between coal bollers and o1l/gas bollers and chooses the average throttle conditions for each type of boller. The throttle conditions determine the amount of electricity produced by cogeneration per pound of process steam.

For conventence, we assume that all bollers in the model have a 30year lifetime. The model starts with 30 cohorts of each of the 16 types of boilers. (This data base is the output of the Boller Stock Module.) Each year the investment module adds a new cohort to the boller stock and retires the 30-year-old cohort of bollers.

The demand for steam, the supply of bark and spent 11quor, and the investment in new bollers are independent exogenous inputs to the model. If there is too much investment in bollers, the capacity factors will fall; If there is too little investment, the capacity factors will rise. A user of the Penetration Model may need to run the model several times to achleve proper capac1ty factors.

The Investment Module uses a simulation algorithm, not an optimization algorithm. If the module used an optimization algorithm, all new purchased-fuel bollers would be the type with the lowest life cycle cost. Historically, the paper industry has purchased a mix of bollers. Even if each manager chooses the boller with the lowest life cycle cost, the cholce will vary from plant to plant due to regional differences in prices and the existing capital stock at the plant.

The Industry Sector Technology Use Model (ISTUM) developed by Energy and Environmental Analysis (5) uses a cost-frequency distribution for each 
process option and defines the market share as the fraction of the total market in which. the process option will be able to provide energy service more cheaply than any competitor. In ISTUM the market shares are calculated numerically.

Conceptually, the ISTUM approach is appealing. However, numerical integrations are inconvenient. In developing ORIM (2), we showed that if the cost frequency distributions were Wetbull distributions, the market shares could be calculated analytically. The result is as follows:

$$
z_{j k}=\lambda \cdot \beta_{j} \cdot\left(L_{j k}\right)^{\rho}
$$

where $z_{j k}$ is the stock of bollers of type $j$ installed in year $k$; $\lambda$ is a normalization factor to match the exogenous total investment in bark, spent liquor, and purchased-fuel bollers; the $\beta_{j}$ are coefficients; $\rho$ is a parameter; and $L_{j k}$ is the $11 f e$ cycle cost of boller type $j$ in year $k$. Equation 3 has often been used to calculate market shares; it has been used In the SRI-Gulf Model (6) and in the CONAES study (7).

The parameter $\rho$ controls the price response. If $\rho$ is zero, the market shares do not respond to changes in life cycle cost. If $\rho$ is a large negative number, the type of boller with the lowest life cycle cost will capture most of the market. CONAES used a vlaue of $\rho=-2$. ORIM uses a value of $\rho=-8$. The results in this report are based on the value $\rho=-4$. If $\rho=-4$, a 10-percent increase in relative cost of a boiler option will cause a 32-percent decrease in investment. 
Investment decisions are influenced by factors in addition to life cycle cost. The coefficients $\left(\beta_{j}\right)$ are used to capture the effect of these additional factors. If all of the coeffictents are equal to 1.0 (as they are in ORIM), investment decisions are made on the basis of life cycle cost alone. If all of the coeffictents were equal to 1.0 in the Penetration Model, the model would forecast too large a penetration rate for coalbollers and high cogeneration boilers. The coeffictents used in the Pene= tration Model are shown in Table 6. The values of the coefficients were chosen to preserve the pre-embargo pattern of investment at pre-embargo prices. The coefficients were chosen to match the pre-embargo pattern qualitatively rather than quantitatively; Figures $15,17,19$, and 21 in the next section show how the forecast pattern matches the historical pattern. For spent liquor, bark, and oll/gas bollers, the coefficients penalize high cogeneration bollers. For coal bollers the coefficients penalize bollers that have no cogeneration. For example, if the life cycle costs were the same for coal and ofl/gas bollers, when both have no cogeneration (Type A),

TABLE 6. COEFFICIENTS FOR THE INVESTMENT DISTRIBUTION FUNCTION

\section{Energy Carrler}

\begin{tabular}{ccccc}
$\begin{array}{c}\text { Throttle } \\
\text { Conditions }\end{array}$ & $\begin{array}{l}\text { Spent } \\
\text { Liquor }\end{array}$ & Bark & Coal & 011/Ga \\
\hline A & 2.0 & 2.0 & 0.5 & 2.0 \\
B & 0.5 & 0.5 & 1.0 & 1.0 \\
C & 0.5 & 0.5 & 1.0 & 1.0 \\
D & 0.1 & 0.1 & 1.0 & 0.5
\end{tabular}


the market share for the o1l/gas bollers w111 be four times as large as the share for coal boilers.

THE COST MODULE

The Cost Module is shown in Figure 7. The inputs to the Cost Module are the factor prices and the boiler I-0 coefficients. The outputs from the Cost Module are the operating cost, the capital cost, and the Iffe cycle cost for each type of boller.

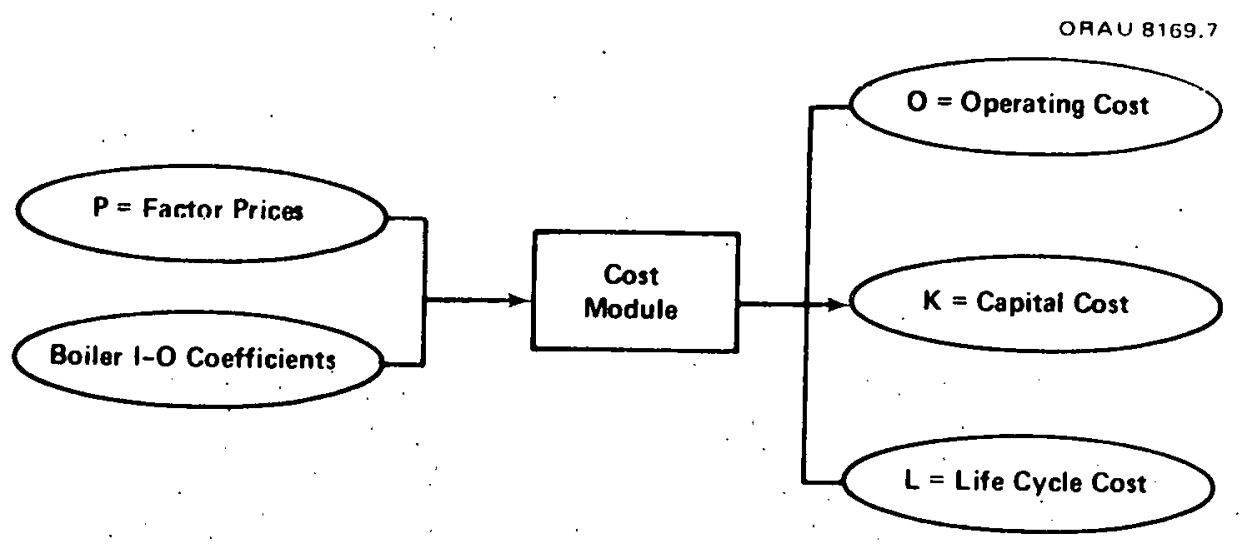

Figure 7. The Cost Module

The operating cost $\left(0_{j k}\right)$ and the capital cost $\left(K_{j k}\right)$ are given by

$$
\begin{aligned}
& 0_{j k}=\sum_{1=1}^{6} P_{1 k} a_{1 j} \\
& k_{j k}=P_{7 k} a_{7 j}
\end{aligned}
$$

where $P_{1 k}$ is the price of factor $i$ in year $k$, and $a_{1 j}$ is the input of factor $i$ to boller type $j$. The seven types of factor inputs are shown in Table 7 . 
TABLE 7. FACTORS OF PRODUCTION FOR THE BOILER OPTIONS

1 Factor Units

\begin{tabular}{lll}
\hline & Spent liquor service & $10^{12} \mathrm{Btu}$ \\
2 & Bark service & $10^{12} \mathrm{Btu}$ \\
3 & Coal service & $10^{12} \mathrm{Btu}$ \\
4 & Oil/gas service & $10^{12} \mathrm{Btu}$ \\
5 & Electricity & $10^{9} \mathrm{kWh}$ \\
6 & Materials and labor & $10^{6} 1976 \$$ \\
7 & Capital & $10^{6} 1976 \$$
\end{tabular}

The 11fe cycle cost is defined by

$$
r_{j k}=\sum_{\sum_{m=0}^{29} \frac{\sum_{j k+m}}{29} \frac{C_{m}}{(1+\gamma)^{m}}}^{(1+\gamma)^{m}}
$$

where $C_{j k}$ is the total cost of boiler type $j$ in the year $k$ $\left(C_{j k}=O_{j k}+K_{j k}\right) ; F_{m}$ is the load factor for each type of boller in year $\mathrm{m}$; and $\gamma$ is the discount rate. Each of the 16 types of boilers has a nominal capacity factor that is used to calculate the capital cost. The load factor in Equation 6 is used to express the temporal variation in the use of each type of boller. The results in this report are for $F_{\mathrm{in}}=1$. Thus, we have assumed that there was no temporal variation in boiler utilization. 
The Penetration Model begins with a base year. (1976) and will forecast energy demand for a 30-year perlod (1976-2005): Each year the model calculates the life cycle cost for each type of boller, and the life cycle cost requires factor prices for 30 years in the future; that is, the botlers Installed in 2004 w111 operate In 2005 and w111 run unt11 2034. Thus, the model requires prices for: fuel, electricity, materials, labor, and captal from 1976 to 2034 .

THE BOILER TECHNOLOGY MODULE

The Botler Technology Module is shown in Figure 8. The Boller Technology Module is the first of the three modules used to prepare the data base. The inputs to the module are technological options (back-pressure turbine versus a condensing turbine, temperature and pressure of steam from the boller, the number of feedwater heaters, and the

ÖAU 8169.8

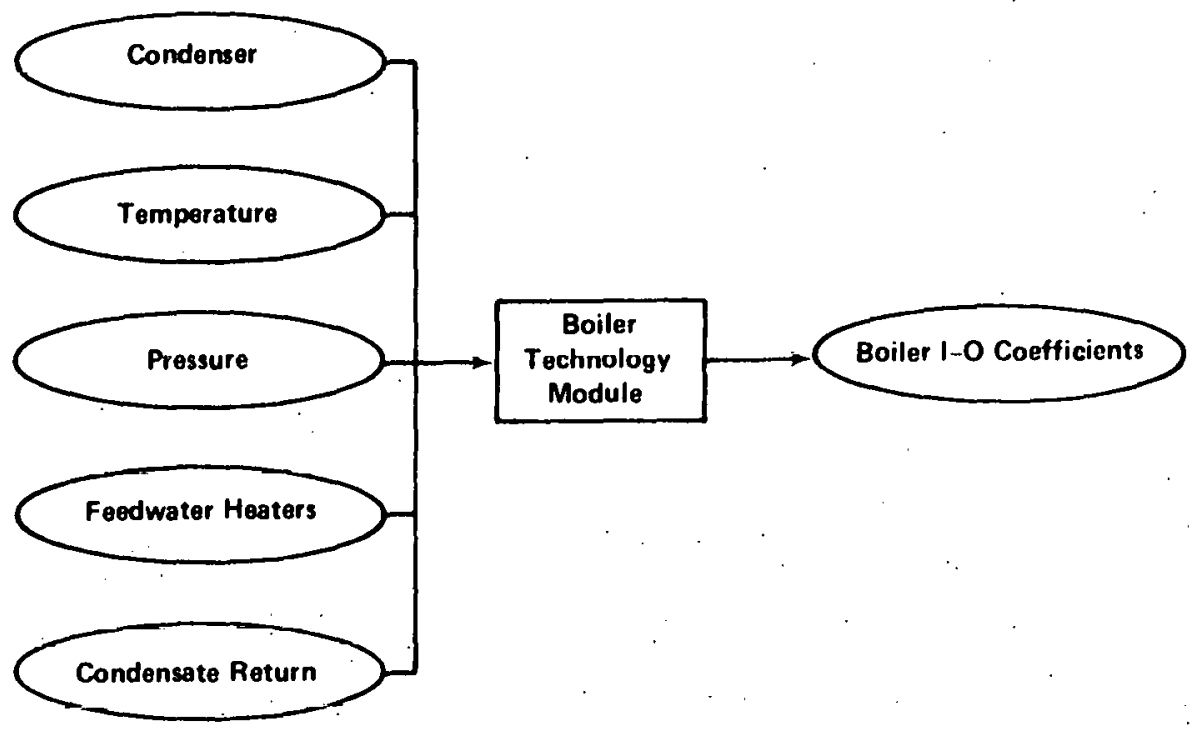

Figure 8. The Boiler Technology Module 
amount of condensate that returns from the process), and the outputs are the energy service $\mathrm{I}-\mathrm{O}$ coefficients for each type of botler.

Calculations were performed using the detalled version of the module, which we shall call the Major Boller Model, shown in Figure 9. The Major Boiler Model was developed by A. R. Major of the J. E. Sirrine Company (8).

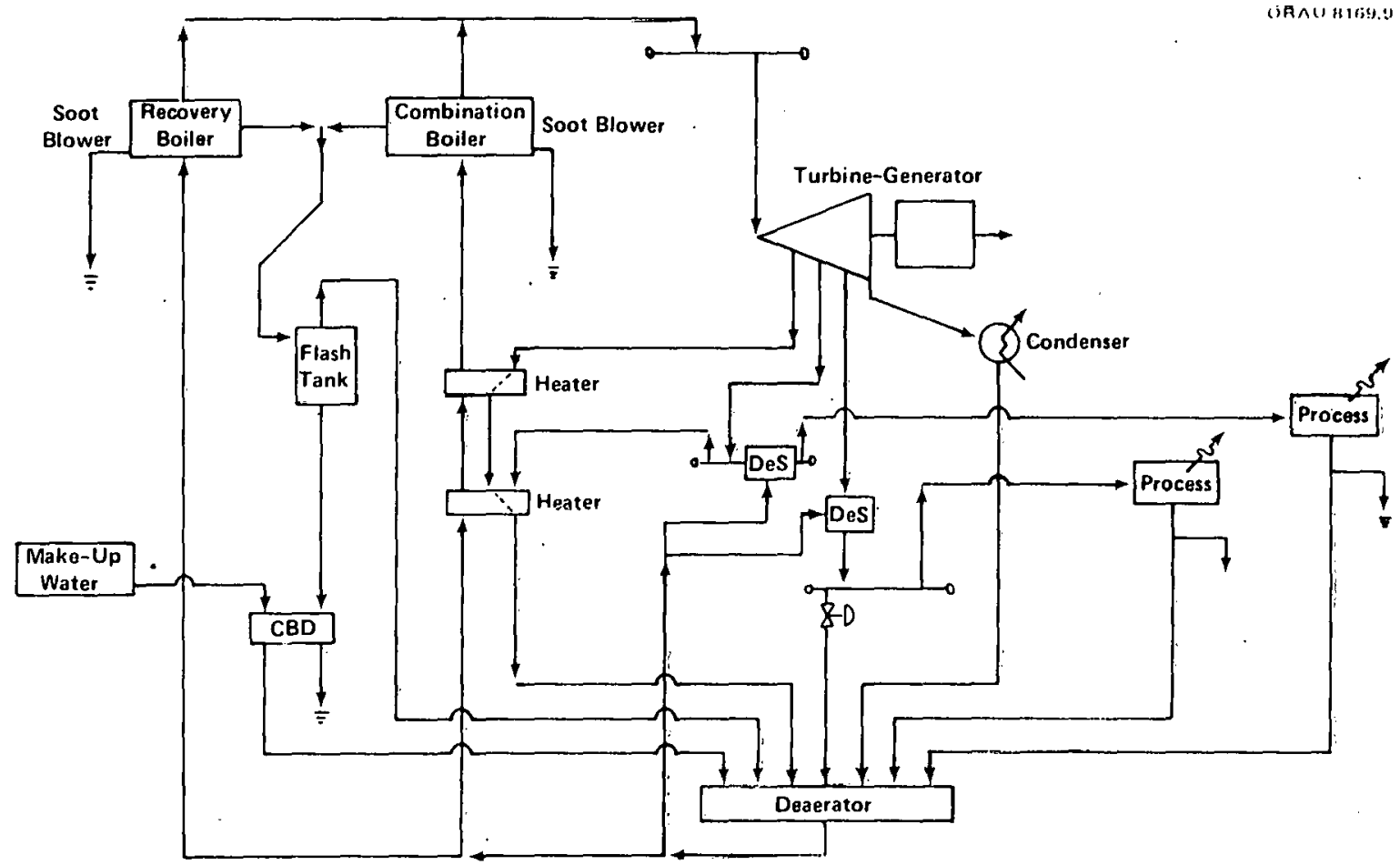

$\mathrm{CBD}=$ Continuous Blowdown Heat Exchanger DeS = Desuperheater

Figure 9. The Major Boiler Model

The Major Builer Model is a flexible representation of the energy service sector of a papermill. The model can use a spent liquor recovery 
boller or a fuel boiler. The model can allow zero, one, or two feedwater heaters for the fuel boller. (Feedwater heaters are not desirable for a recovery boiler.) The turbine options in the model are a condensing cycle or back-pressure turbine. The model supplies process steam at two different pressures and the amount of condensate returned from the process steam is a significant variable.

To use the Major Boiler Model to estimate the energy service I-O coeffictents for the 16 types of boilers, we have selected typical values for the parameters in the model. Since a data base does not exist, the parameters were chosen after discussions with experienced engineers. Although the Major Boiler Model is a flexible representation of the energy service sector of a papermill, other technological options exist. For example, in a recent paper, R. H. Williams of Princeton University discusses options for industrial cogeneration (29). His emphasis is on maximum production of electricity per pound of process steam and selling the surplus electricity. The structure of the Penetration Model is flexible enough to study the surplus electricity issue, but we have not chosen to develup the data base required to study th1s 1ssue.

The seven factors of production for the boiler options are listed in Table 7, above. The first flve factors are the amount of fuel service to produce a billion pounds of process steam and the amount of electricity produced. The amount of fuel service is the energy delivered to the water to produce high-pressure steam. For a fixed output of process steam, as the throttle conditions are increased, the generator produces more elec- 
trictty and the demand for fuel service increases. The Major Boller Model has two types of bollers--a recovery boller and a combination bofler. The recovery boller burns spent liquor, and the combination boller can burn bark, coal, fuel oil, or natural gas. Since the combination boiler has feedwater heaters, it requires less energy service than the recovery boller to produce the same output of process steam and electricity. We have used the Major Boller Model to estimate the demand for energy service by either the recovery boller or the combination boiler for each of the four sets of throttle conditions. The detalls are in the data appendix.

The Major Boiler Model produces estimates of the demand for fuel service and the production of electricity for each of 16 boiler options. The other two factors of production in Table 7 are materials and labor and cap1tal; estimates of the I-O coefficients for these factors are developed in the data appendix.

The fuel boller in the Major Boller Model is a combination boller that can burn bark and fuel. We have chosen to model combination bollers as two separate boilers--a bark boiler and a purchased-fuel boiler.

A back-pressure turbine has a fixed ratio between electricity and process steam. To allow flexibility, a papermill can purchase electricity or install a condensing turbine. A choice between these options requires careful cost analysis and depends on the rate structure of the electric utility. The heat rate for a condensing turbine in the Major Boiler Model 18 about $13,800 \mathrm{Btu} / \mathrm{kWh}$. A typical ut1lity heat rate 18 about 10,500 Btu/kWh. If there are 10-percent distribution losses, the delivered heat 
rate 18 about $11,700 \mathrm{Btu} / \mathrm{kWh}$. Thus, a condensing turblne does not save energy. The grid should allow the utility to have a higher load factor for Its capltal stock than the load factor for the capital stock at the paperm111. (W111fams proposes that the utilities own the capital that produces energy service at papermills. Although his proposal would encourage cholces based on marginal costs, radical instltutional changes are hard to implement.) Thus, we conjecture that the marglnal cost of backup electric1ty from a condensing turbine should be higher than the marginal cost of utility electricity. (Utility rate structures are not based on marginal costs, and cost analysis may justify a condensing turbine at certain locations.) In the model we assume that all boller options use back-pressure turbines.

THE BOILER STOCK MODULE

The Boller Stock Module is shown in Figure 10. Using data from the American Paper Institute (API) (10), the American Boller Manufacturers Association (ABMA) (11), and the Major Fuel Burning Installation Survey (MFBI) (13), the Boller Stock Module estimates the total stock of each type

ORAU 8169.10

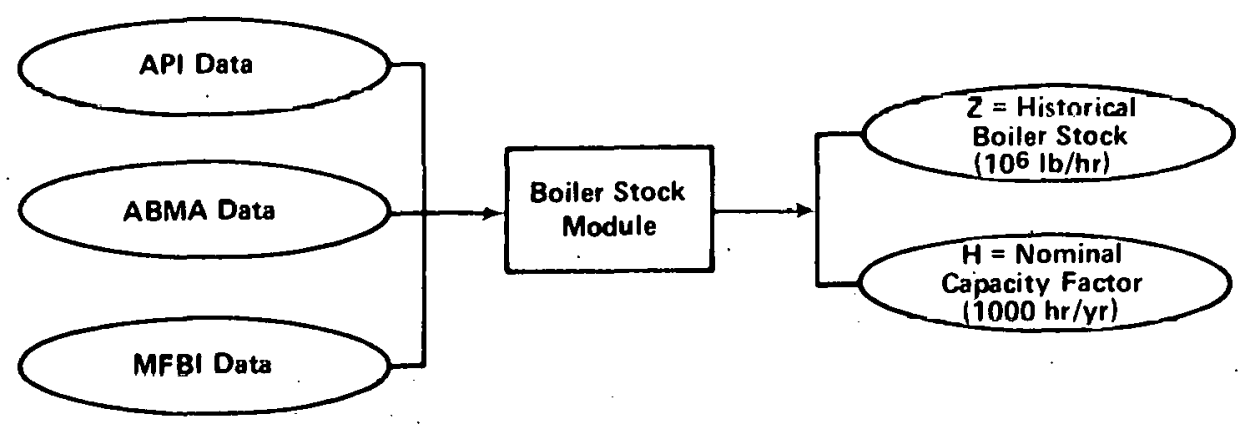

Figure 10. The Boiler Stock Module 
of boller in the base year (1976), the nominal capacity factor for each type of boller in the base year, and the stock of bollers by type for the 30 years preceding the base year. Details on the methods and results of the module will be given in the data appendix.

THE CAPITAL PRICE MODULE

The Capital Price Module is shown in Figure 11. Given income tax pulley, propery tax policy, the Interest rate on bonds, and payments to stockholders, the capital price module determines the appropriate capital price (rate of return on capital). The methodology for determining the capital price has been discussed in the paper by Phung (14). The Capital Price Module is not a formal computer program but is a side calculation performed by a user of the model. Our estimate of the appropriate capital price for the paper Industry is 22 percent per year in constant dollars.

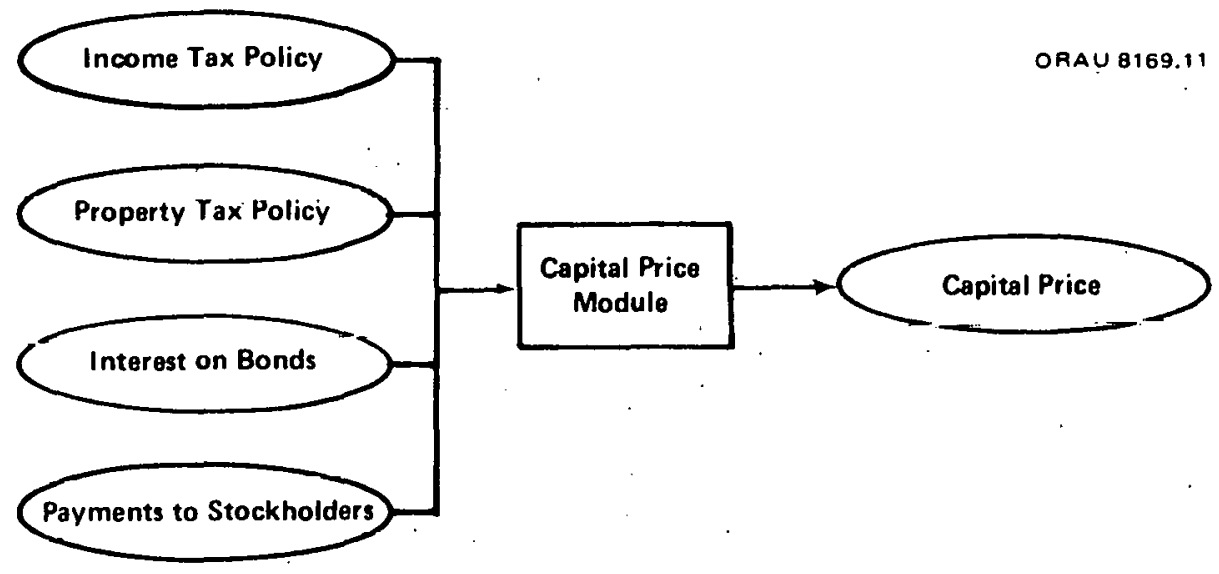

Figure 11. The Capital Price Module 


\section{ANALYSIS OF POLICY ALTERNATIVES}

This section concludes with a brief discussion of how the Penetration Model can ald the analysis of policy alternatives. The policy alternatives include changes in Income tax policy, a Btu tax or government orders that a11 new bollers consume coal, and new technology.

Changes in income tax policy, such as deprectation allowances or tax credits, directly affect the price of capital, which is one of the factor prices (see Table 2).

A Btu tax on o1l/gas would encourage investment in coal bollers and Increase the premature retirement of oll/gas bollers. Government orders that a certain class of new bollers burn. coal can be simulated by using a Btu tax to Increase the share of coal bollers to hit the appropriate target.

Research and development (R\&D) policy can produce new process options. Given the $I-0$ coefficients for a new technology, the model can forecast the penetration of the new technology and estimate the energy savings for the new technology. Thus; the Penetration Model can provide an estimate of the benefits from energy $R \& D$. 
THIS PAGE

\section{WAS INTENTIONALLY \\ LEFT BLANK}


CHAPTER 3

RESULTS OF THE PENETRATION MODEL

The previous chapter presented the model. A natural sequence would be to present the data base in this section and the results in the next section. To make this report interesting to a general audience, the details of the Boller Stock Module and the results of the Boller Technology Module are presented In a data appendix. (The detalls of the Boiler Technology Module are too complex for a general audience and too elementary for power englneers and w111 not be presented. The detailed equations of conservation of energy and mass can be written directly from Figure 9.) The results of the Penetration Model will be presented using 14 figures. To preserve the continuity of the text, Figures 15-25 are at the end of this chapter.

The results of the Penetration Model are presented for three scenar1os: High Price, Medium Price, and Low Price. The model requires prices from the base year (1976) to 2034 for the seven factors shown in Table 5 . For the three scenarios all of the factor prices are constant, except the price of o1l/gas service, which is shown in Figure 12. The price shown in Figure 12 is a price index with an initial value of 1.0 in 1976. (In physical units, the base year price for ofl/gas service is $\$ 2$ per million Btu.) In the High Price scenarlo the ofl/gas price index increases to 4.0 by 2000 and remains at that value thereafter. In the Medium Price scenario the price Index increases steadily to 2.0 in 2000 and 3.0 in 2034 . In the Low Price scenario the price index remalns at 1.0 from 1976 to 2034 . 


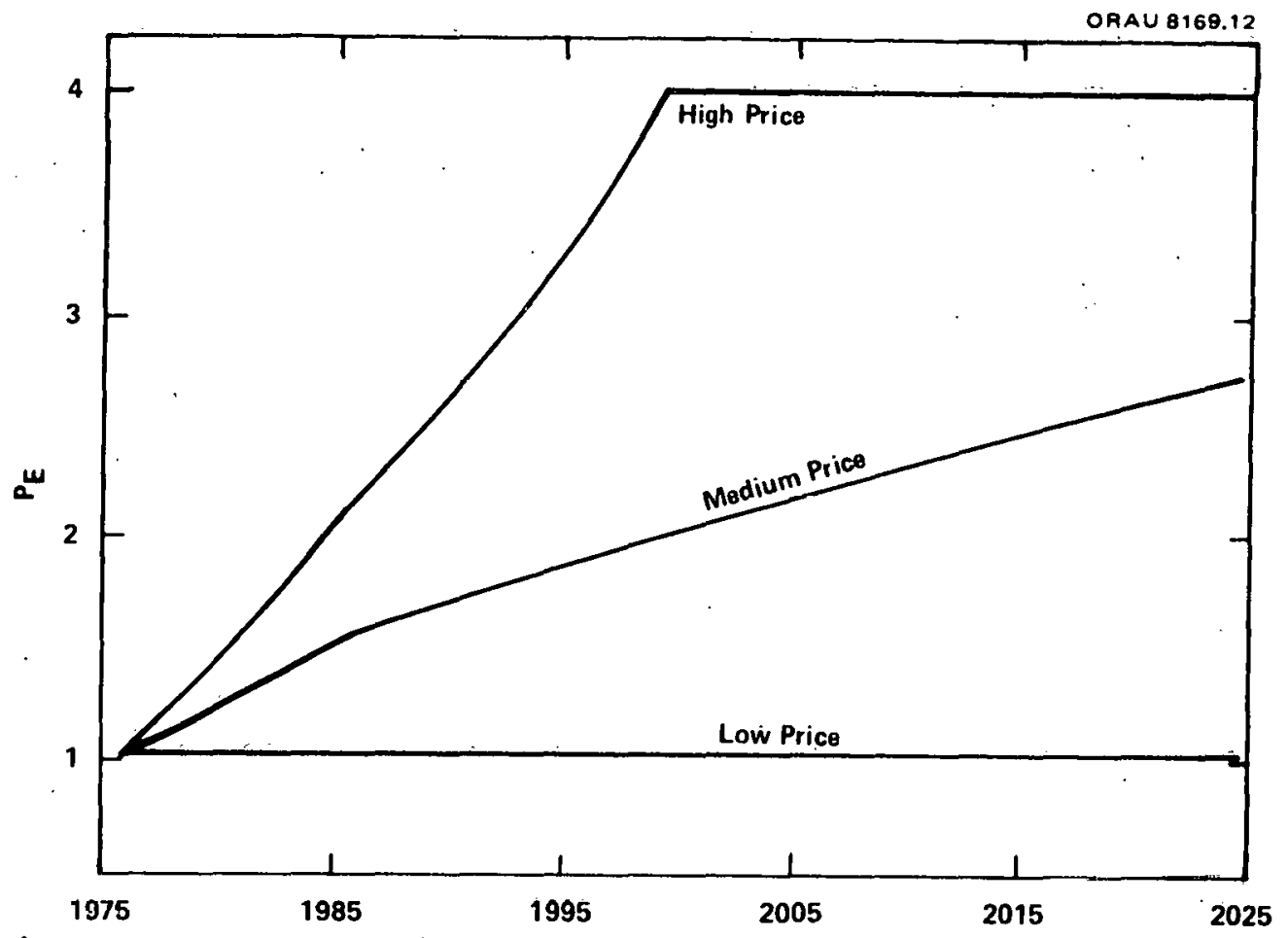

Figure 12. The Price Index for Oil/Gas Service for Three Sconarios

The demand for oil/gas service and for coal service for the three scenarios is shown in Figures 13 and 14. The demand for oil/gas service doubles by 2005 in the Low Price scenar1o, while the demand for coal service is almost constant. In the Medium Price scenario the demand for oil/ gas service decreases slowly, while the demand for coal service increases strongly, doubling by 1990 and increasing by a fartor of six by 2005. In the High Price scenario the demand for oll/gas service decreases by more than a factor of ten in 30 years, while the demand for coal service increases by a factor of nine.

To summarize, at current prices fuel oil and natural gas will remain the dominant boiler fuels. If the oil/gas price doubles by 2000 , coal 

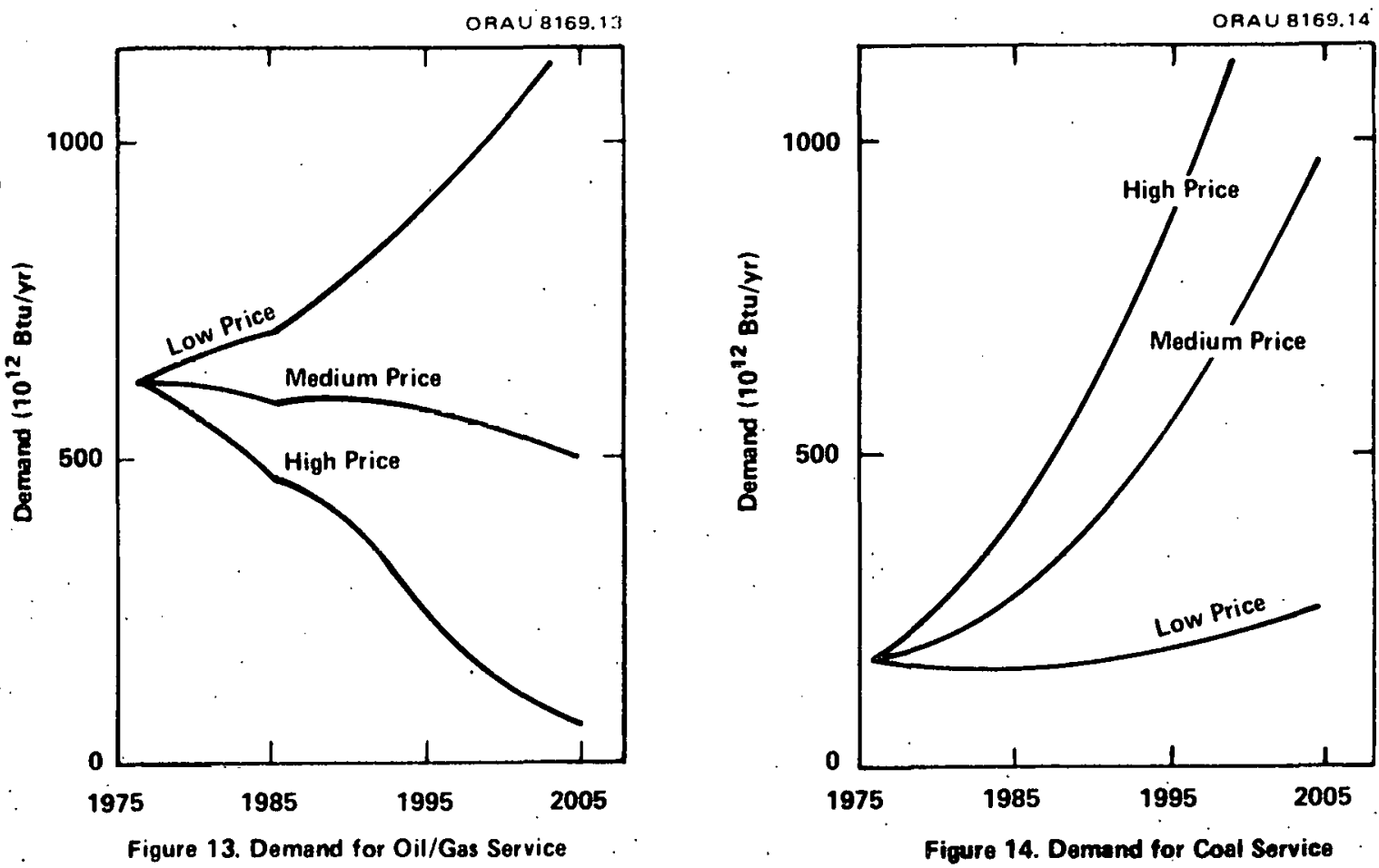

Figure 14. Demand for Coal Service

bollers will penetrate and w111 provide more process steam than o1l/gas, bollers by 1996 . If the oil/gas price quadruples by 2000 , coal bollers will penetrate rapldly and will provide more process steam than $011 /$ gas bollers by 1986 .

Figures 13 and 14 present the results of the Penetration Model. To understand the results, Figures 15 through 22 present detalls on the installed capacity of four of the eight types of purchased-fuel bollers. Figures 15, 17, 19, and 21 show the market share of each type of boller by year of Installation from 1946 to 2004. Figures 16, 18, 20, and 22 show the total capacity of each type of boller from 1976 to 2005. 
Figure 15 displays the market share for coal bollers of type A. (The 16 boller options are defined in Table 5. Type A bollers produce no electricity.) In 1946, the market share was 6.5 percent; by 1976 the market share was nearly zero. Thus, type A coal bollers have lost their market share in the last 30 years. The Penetration Model forecasts three market share scenarios for the perfod 1976 to 2004; In the Low Price scenarto the market share is about 1 percent; in the Medium Price scenario the market share increases from 2 percent to 3 percent; in the High Price scenario the market share increases from 3 percent to 4 percent. Even for the High Price scenar10, the forecast market share is less than the historical narket share in 1946.

Figure 16 displays the total boller capacity for coal bollers of type A, measured in units of millions of pounds per hour. (Figure 15 displays market shares for annual boller sales. Figure 16 displays market shares for total stocks of boilers. Since Figure 16 is a 30 -year. summation, it does not have any discontinuities in the base year as in Figure 15.) In the Low Price scenario retirements of old bollers are greater than add1tions of new boilers until 1993, and the total capacity decreases. After 1993, the total capacity Increases, and it is slightly greater than the Inttal capacity by 2005. In the Medium Price scenario the total capacity Increases by a factor of four by 2005. In the High Price scenario the total capacity increases by a factor of five by 2005 .

The market share for coal bollers' of type D is shown in Figure 17. The market share increased to more than 8 percent in 1952 before decreasing 
to less than 2 percent by 1975. The Penetration Model forecasts three market share scenarios: the market share 18 about 3 percent for the Low Price scenarlo; the market share 1ncreases from 6 percent in 1976 to 11 percent in 2004 for the Medium Price scenar1o; the market share Increases from 11 percent in 1976 to 14 percent in 2004 for the High Price scenario.

Figure 18 displays the total boller capacity for coal boilers of type D. In the Low Price scenario the total capacity increases steadily but slowly from 10 to 17 million pounds per hour. In the Medium Price scenario the total capacity increases by a factor of six by 2005. In the High Price scenario the total capacity increases by a factor of nine by 2005 .

The market share for o1l/gas bollers of type $A$ is shown in Figure 19. The peak market share was 29 percent in 1966; the 1975 market share was 28 percent. In 1975, oll/gas bollers of type A have the largest market share of all of the 16 types of bollers. The Penetration Model forecasts lower market shares for oll/gas bollers of type $A$ for all three scenarios. In. the Low Price scenario the market share decreases from 15 percent in 1976 to 14 percent In 2004. In the Medium Price scenario the market share decreases from 13 percent in 1976 to 6 percent in 2004. In the High Price scenarto the market share decreases from 8 percent. In 1976 to 2 percent in 2004 .

Figure 20 displays the total capacity of oil/gas bollers of type A. The t.nt.al c.apacity Increases from 60 to 93 million pounds per hour in the Low Price scenario. The capac1ty Increases to 73 in 1989 before decreasing to 56 in 2005 in the Medium Price scenario. The total capacity increases 
to 63 in 1983 before decreasing to 20 in 2005 in the High Price scenario. Although the forecast market share in the High Price scenario is always lower than the historical share, a smaller fraction of a larger market causes the new capacity to be larger than the retired capacity for the pertod 1976 to 1983 .

In the Low and Medium Price scenarios saturated (type A) o11/gas boilers have a larger market share and a larger total capacity than saturated coal bollers throughout the 30-year forecast period. In the High Price scenarlo saturated oil/gas bollers have a larger market share than coal unt11 1984 and a larger total capacity unt11 1996.

The market share for oil/gas bollers of type $C$ is shown in Figure 21. The market share decreased from 24 percent in 1946 to 7 percent in 1975 . In the Low Price scenario the model forecasts a 10-percent market share. In the Medium Price scenario the model forecasts a decrease from a 7percent share in 1976 to a 3-percent share in 2004. In the High Price scenarto the forecast market share decreases from 4 percent in 1976 to 1 percent in 2004.

Figure 22 displays the total capactity of ofl/gas bollers of type $C$. In the Low Price scenario the capacity increases by a factor of two. In the Medium Price scenario the capacity is constant. In the High Price scenarto the capacity decreases by a factor of three.

The model forecasts the penetration rate for cogeneration as well as for coal bollers. Figures 23, 24, and 25 present the cogeneration forecast for the three scenarios. The three scenarios were designed to 11lustrate 
penetration of coal bollers rather than cogeneration. The primary variable that influences the penetration of cogeneration is the price of electric1ty. Substantial changes in the cogeneration penetration rate can be achieved by large changes in electricity price.

The demand for purchased electricity is shown in figure 23. The demand Increases by about a factor of four for all three scenarios. The difference between the demand in the High Price scenario and the demand In the Low Price scenario is about 10 percent. The cogeneration of electric1ty is shown in Figure 24. The production of electricity as a by-product of steam production Increases by about a factor of three in all three scenarios. The difference between cogeneration in the High Price scenario and In the Low Price scenario is about 17 percent. (The difference in cogeneration is equal in magnitude to the difference in purchased electrictity. Since the amount of purchased electricity is greater than the amount of generated electricity, the percentage difference is smaller for purchased electricity.)

Figure 25 displays the average power ratio as forecast by the model. The power ratio ts the ratio of by-product electricity and process steam measured in kWh per 1000 pounds of process steam. As shown in the data append1x, the power ratio ranges from zero for a type $A$ boller to 62 for a type D boller. In the Low Price scenarto the power ratio is 27 in 1976 and decreases to 26 in 1987, before increasing to 28 in 2005. The decrease is caused by the retirement of coal bollers with high throttle conditions.' In the High Price scenarlo the power ratio Increases from 27 in 1976 to 33 in 
2005. From 1972 to 1977 the power ratio increased rapidly; linear extrapolation of the recent rapid growth would result in a power ratio of 48 in 2005. An increase in the price of electricity would cause the model to forecast a higher power ratio.

Comparison of Figures 23 and 24 reveals a paradox: the power ratio Increases, resulting in an increased generation of electriclty per unlt of process steam; at the same time, the demand for purchased electricity in: creases more rapidly than the generation of electrictity. In 1976 the demand for purchased electricity is equal to the production of electricity. In the Low Price scenario in 2005, the demand for purchased electricity is 66 percent higher than the production of electricity. In the High Price scenario in 2005, the demand for purchased electricity is 25 percent higher than the production of electricity. The explanation of the paradox is the exogenous assumption that the demand for electricity will increase more rapidly than the demand for process steam. Thus, conservation of process steam encourages greater purchases of electrictity. 

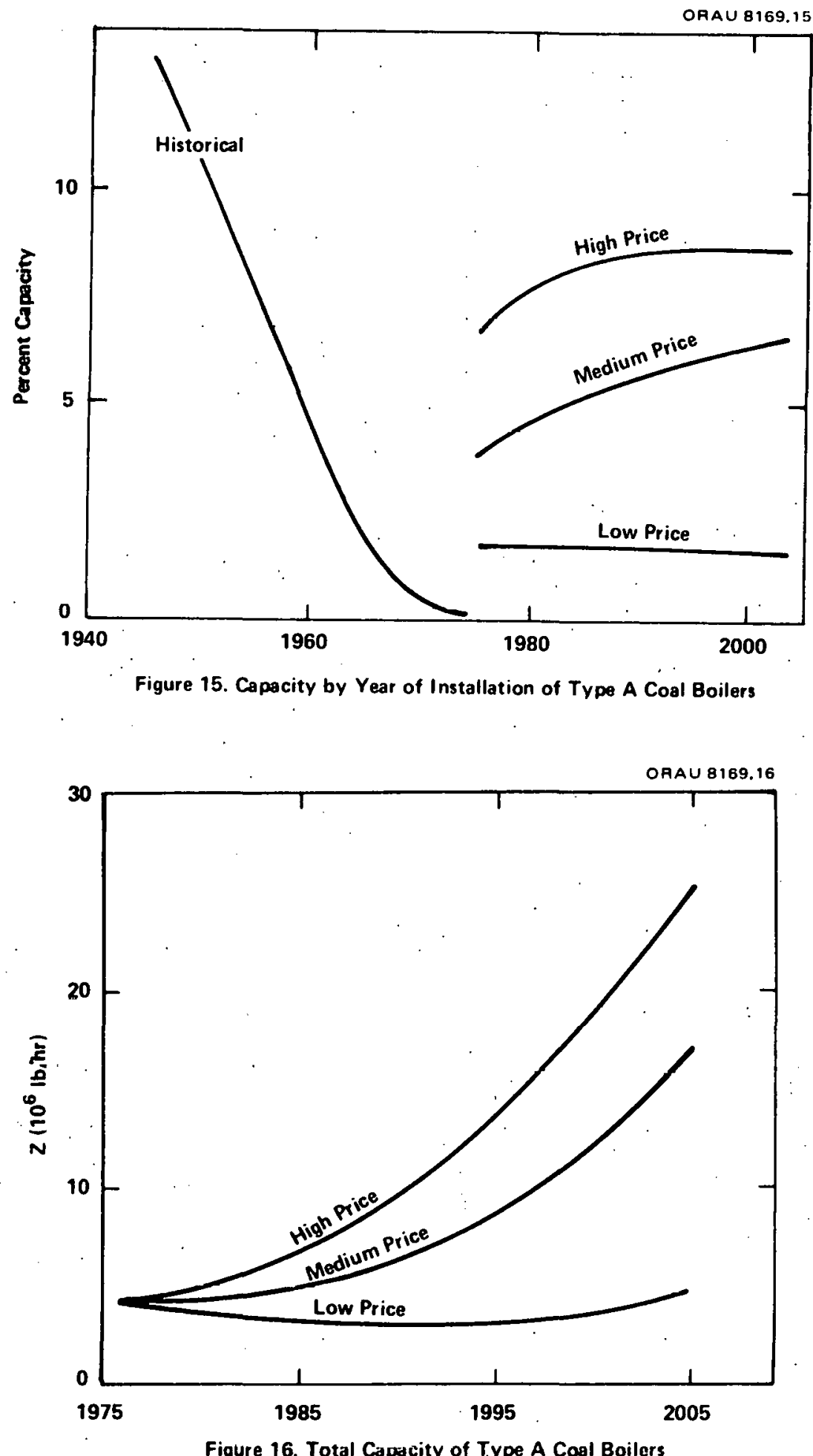

Figure 16. Total Capacity of T.ype A Coal Boilers 


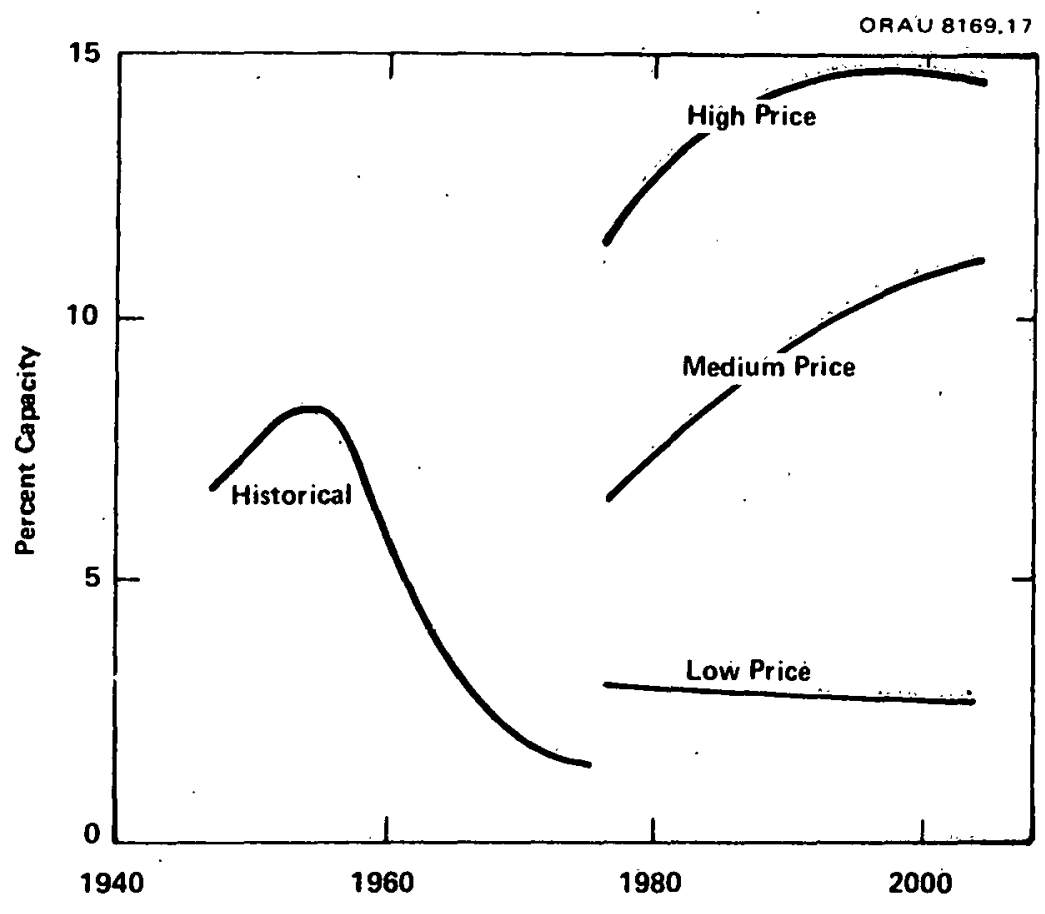

Figure 17. Capacity by Year of Installation of Type D Coal Boilers

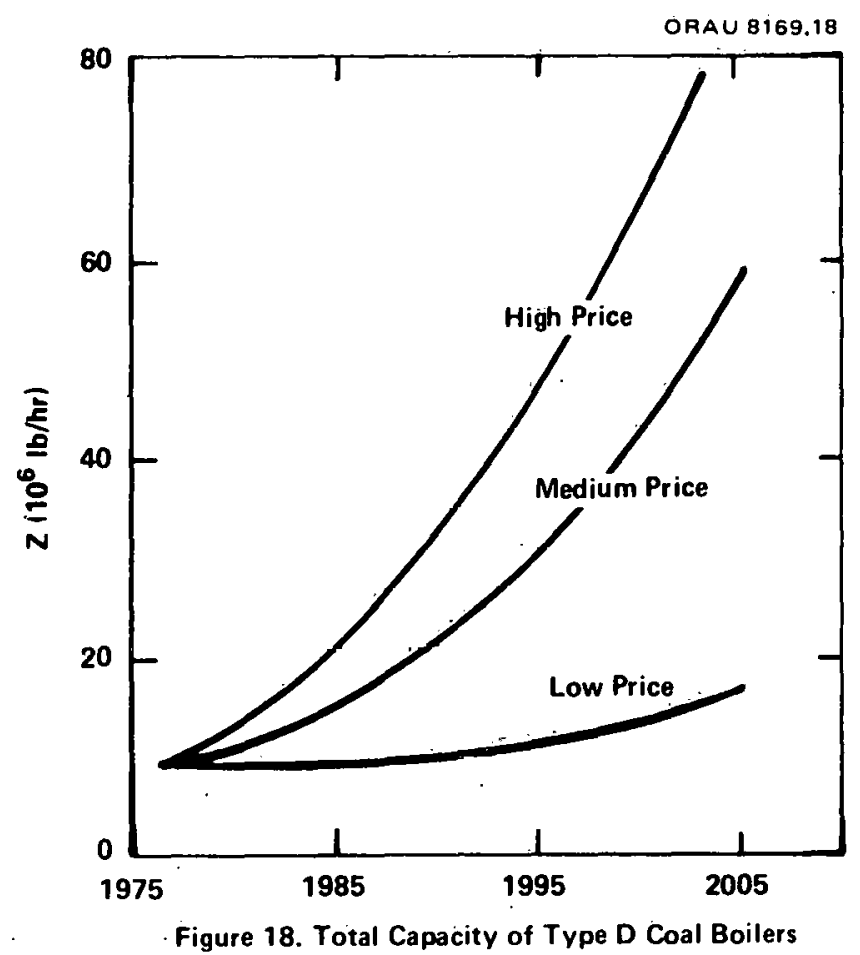




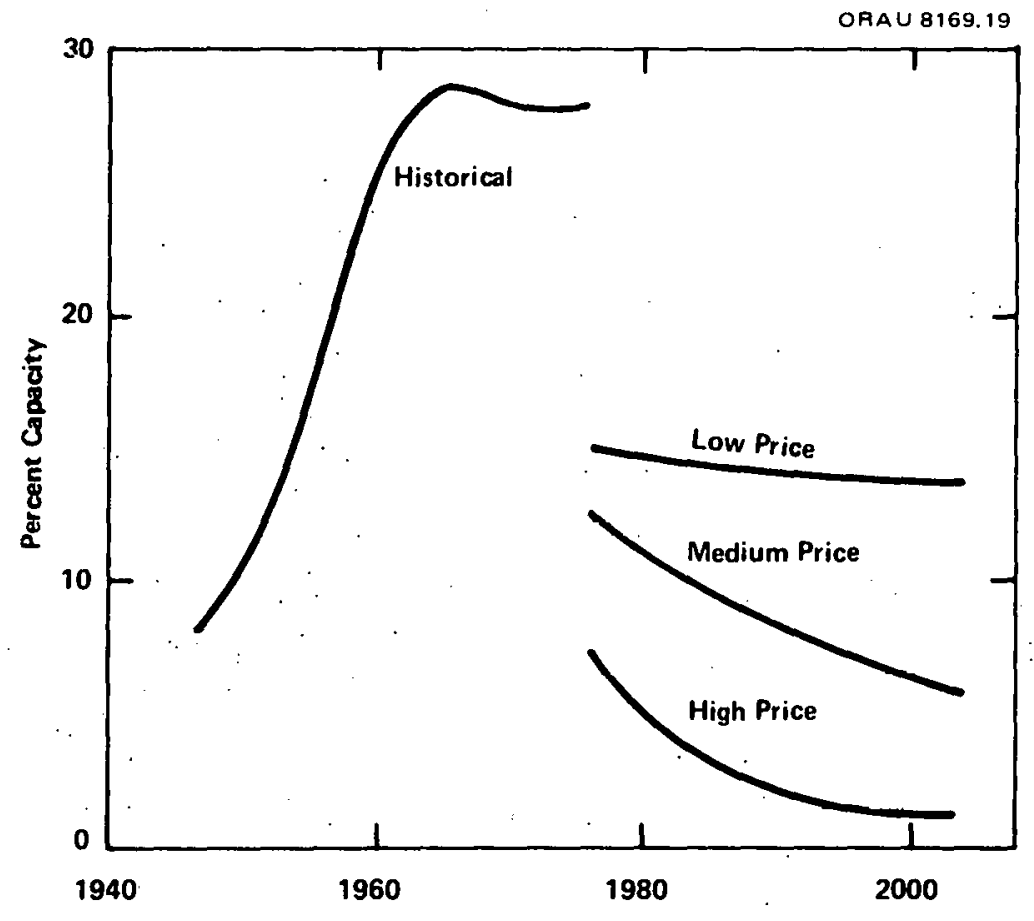

Figure 19. Capacity by Year of Installation of Type A Oil/Gas Boilers

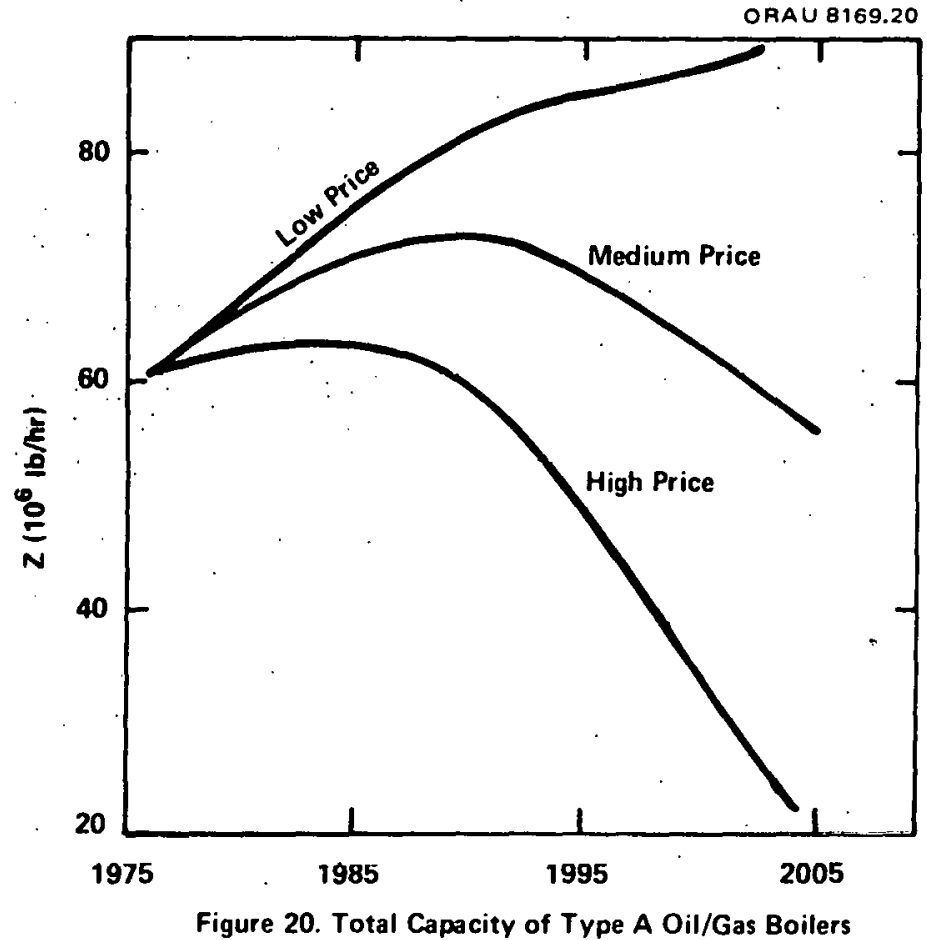




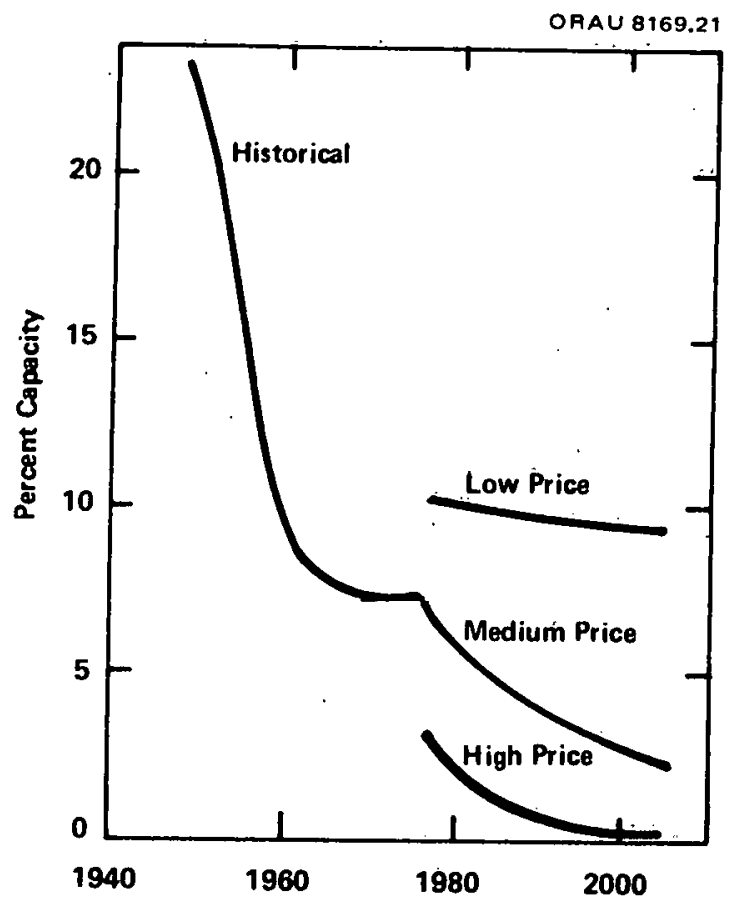

Figure 21. Capacity by Year of Installation of Type C Oil/Gas Boilers

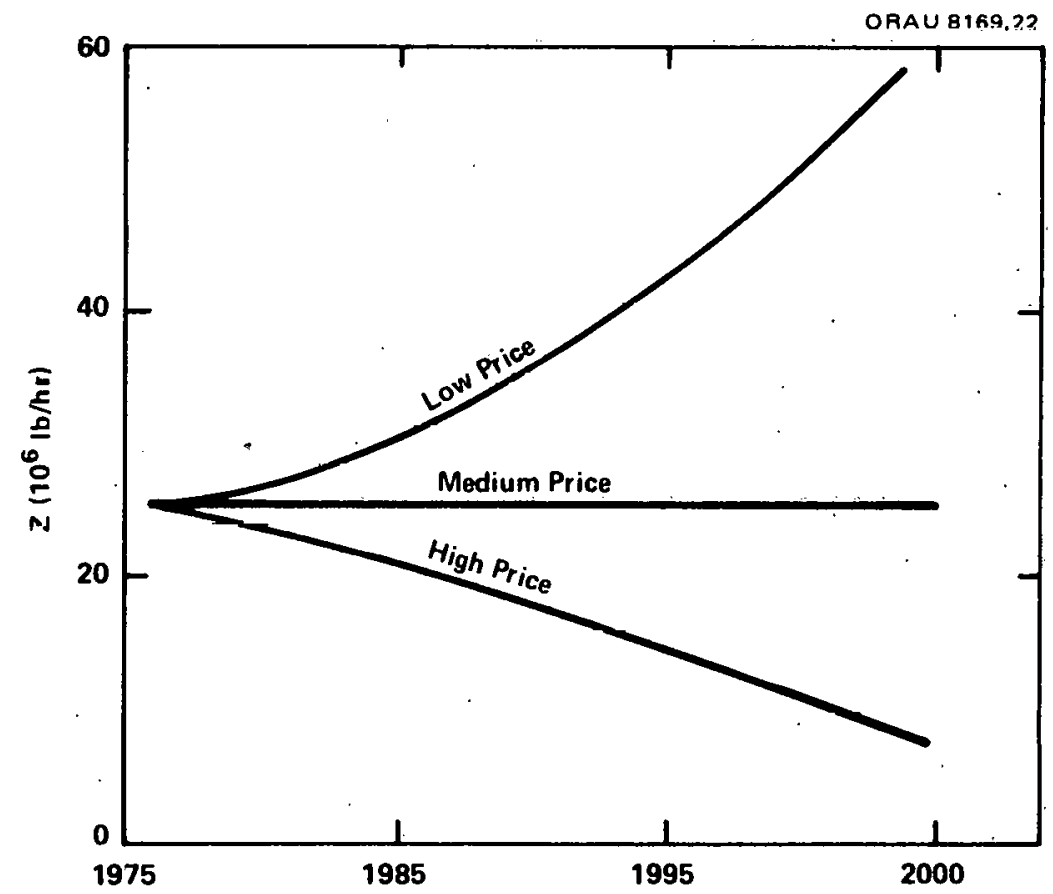

Figure 22. Total Capacity of Type C Oil/Gas Boilers 

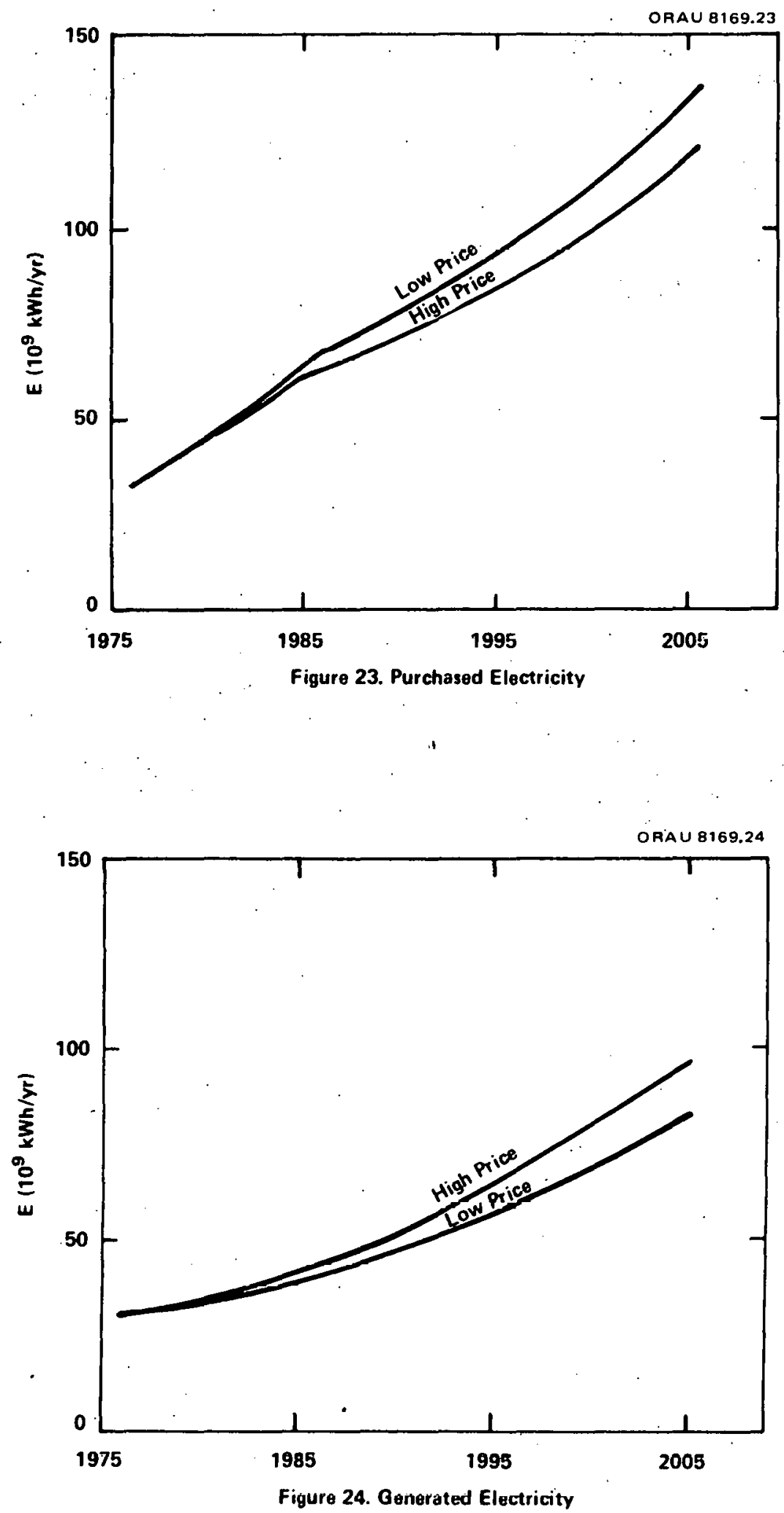


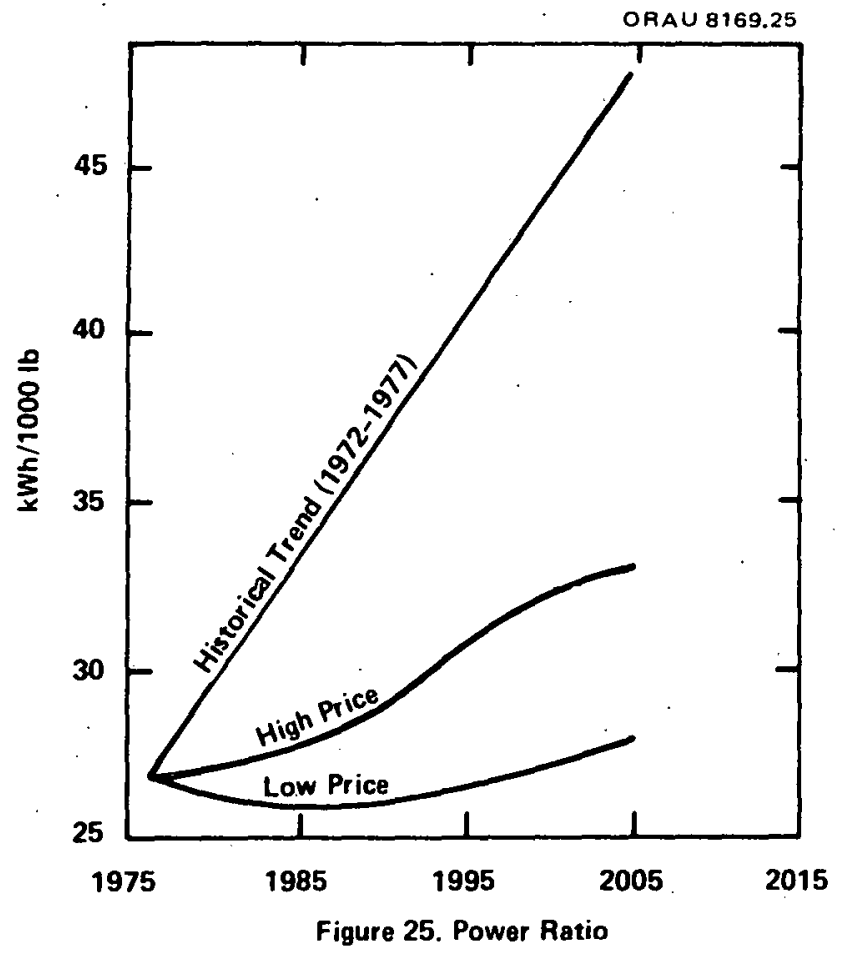




\section{CHAPTER 4}

\section{CONCLUSTONS}

The Penetration Model is an 1mportant milestone on the road to improved energy-demand models for the Industrial sector. It is not the end of the road because the model is designed to be part of a comprehensive model for the paper industry, and the paper industry is only one of many industrial sectors. The model is based on many assumptions and approximations. The approximations could be Improved if better data were avallable. The art of model development is to find a close approximation to reality by using the existing data base.

The conceptual framework of the model provides a solld foundation. The conceptual framework links the demand for energy carriers to the demand for energy services that are linked to the demand for paper products. To be more specific, paper is produced from Inputs of wood, chemicals, energy services, capital, labor, and materials. By-products of paper production are bark and spent 11quor. Energy services (process steam and electricity) are produced from Inputs of energy carriers (purchased fuel and purchased electricity), bark, spent 11quor, capital, labor, and materials. The demand for energy services is driven by the demand for paper products, and the demand for energy service drives the demand for energy carriers.

Conservation can be defined as the link between demand for paper products and demand for energy services; that 1s, the demand for energy service Is equal to the product of demand for paper products and conservation. Fuel shares can be defined as the link between demand for energy services 
and demand for energy carrlers; that 1s, the demand for energy carriers 1s equal to the product of fuel shares and the demand for energy services. With these definitions the Penetration Model is a fuel shares model that requires exogenous information on conservation and the demand for paper products.

Energy carriers are consumed in bollers to produce high-pressure steam, which is expanded in a turbine to produce electrictity and process steam. The stock of bollers determines the demand for coal and ofl/gas. The Penetration Model tracks the movement in new bollers and the retirement of old bollers for 16 types of bollers (combinations of four types of carriers and four types of throttle conditions). Investment in new bollers Is allocated among the 16 types of bollers on the basis of 11 fe cycle cost by using a distribution function.

The distribution function is a significant innovation that we are using for the first time in the Penetration Model. The distribution function is a bridge from the micro level to the macro level. At the micro level each firm chooses the optimal technology for its conditions. Due to differences in local conditions, the macro result of local optimization 18 an incredible diversily in. technology. The paper industry 18 composed of about 800 papermills with about 2,000 bollers. Considering the capacity, throttle conditions, and age for the bollers, each of the 2,000 bollers is unlque; no two boflers have the same age, capacity, and throttle cond1tions.

Development of a macro model that yields the same result as the sum of the micro optimizations is a difficult problem. An unconstrained optimiza- 
tion problem w11l yleld a single "best" solution. A constrained optimization problem can yleld a mixture of solutions, but introduces the complication of forecasting the constraints. Simllarly, if the macro result is the sum of several local optimization problems, a forecast of the local conditions is required. The distribution function is an empirical simulation device that will yield a mixture of results for a single set of average prices.

The credibility of the Penetration Model could be 1mproved by increasing the number of boller uptions; an increase in options could offer reglonal deta1l, size detall, more information on capability to burn alternate fuels, and detall on throttle conditions. The credibility of the model could be Improved by a systematic attempt to estimate the distribution function. However, both increasing the boller options and estimating the distribution function require a greatly improved data base. An 1mproved data base would consist of a comprehensive census of all bollers; census data would include capacity data by reglon, size, fuel and throttle conditions, and year of installation, as well as capttal cost and annual operating cost.

Although the Penetration Model cannot yleld a precise forecast, the model is the result of a compromise to achleve the maximum detall that can be supported by the existing data base. Given the demand for energy services, the model splits the demand between coal and ofl/gas bollers. The basis for the split is the difficulty of retrofitting an existing oil/gas boller to burn coal. Since a natural gas boller can be easily retrofitted 
to burn fuel o11, the model does not attempt to differentiate between bollers that consume natural gas, distillate fuel oil, and residuâl fuel oil. One of the strongest conclusions of our model development effort $1 \mathrm{~s}$ the impossibility of an accurate forecast of fuel shares for ofi/gas bollers. The model splits demand between coal and oll/gas bollers on the basis of capacity and allocates investment to new bollers on the basis of âa distribution function. Although the distribution function is the weakest feature of the model, the data base is too weak to develop a more reliable substitute for the distribution function: 
DATA APPENDIX

Th1s appendix consists of 16 tables that are the data base for the Penetration Model. Table A-l contalns estimates of demand for fuel and electricity by the papermill industry for 1972, 1975, 1976, and 1977. (The papermill industry conststs of SIC sectors 261, 262, 263, and 266. The paper products industry consists of SIC sectors 264 and 265.) The source of the data 18 the American Paper Institute (10). The data in Table A-1 provides the control totals for the Penetration Model.

"Other purchased energy" is primarily crude oil and will be combined with restdual fuel ofl. "Energy sold" is steam and electricity; we assume 1t is 70 percent electricity and 30 percent steam. "Other energy" is purchased solid waste (e.g., sawdust) and will be comblned with bark and hogged fuel.

Table A-2 presents estfmates of demand for purchased fuel and electricity by the paper industry for several years. The data source is the Bureau of the Census (4).

Table A-3 compares the API data to the Census data for 1975 and 1976. The coverage of the Census data is the paper Industry, while the API covers the papermill industry. The Census does not cover all establishments; however, for the paper industry the "fuels not speclfled by kind" is about 1 percent of the total. Thus, the Census claims to have measured 99 percent of the energy consumption in the paper industry.

According to the Census, the paperm111 1ndustry consumes about 93 percent of the total purchased fuel used by the paper Industry. (The paper 
TABLE A-1. ESTIMATED FUEL AND ELECTRICITY DEMAND BY THE PAPERMILL INDUSTRY

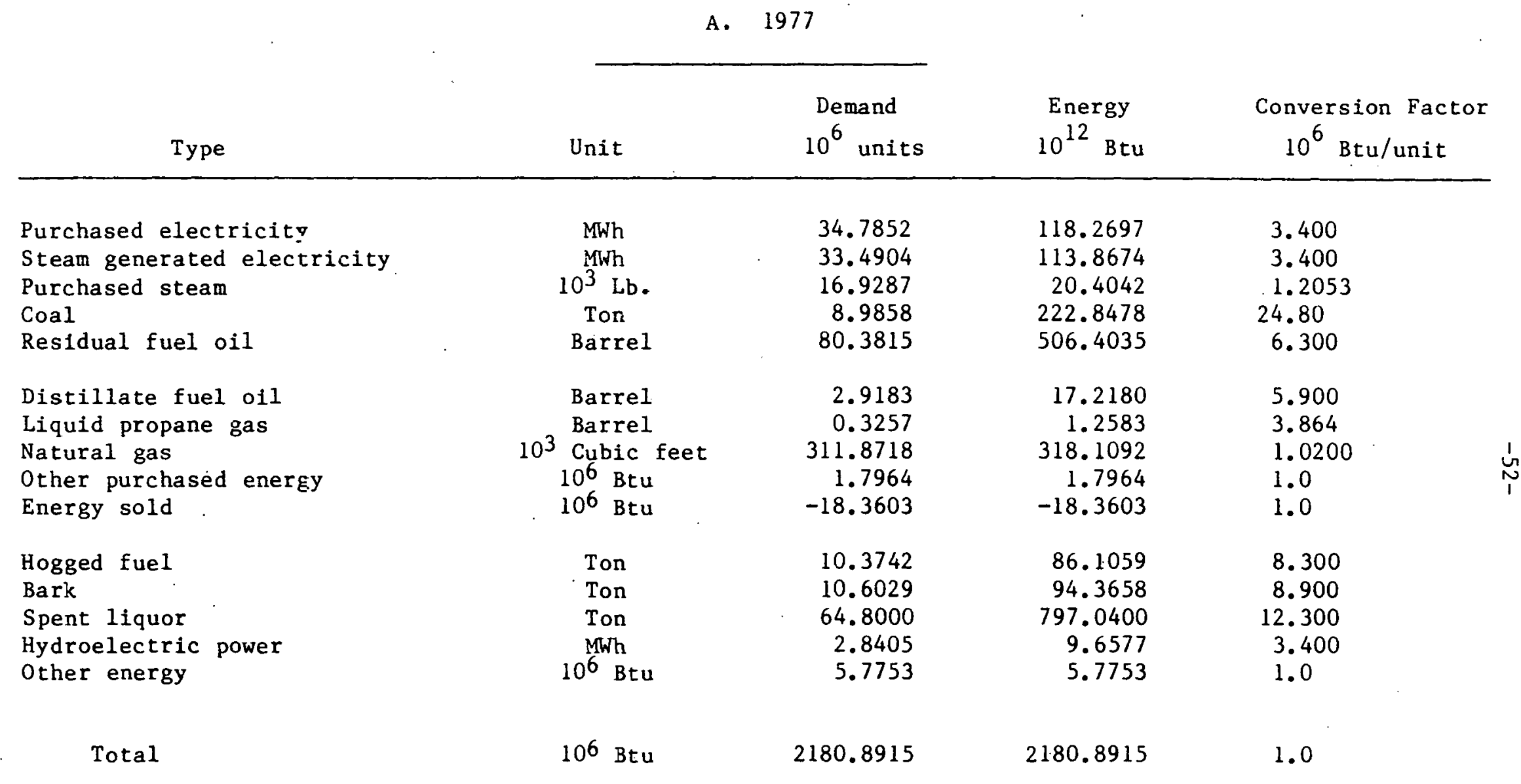

Source: American Paper Institute (10). 
TABLE A-1. ESTIMATED FUEL AND ELECTRICITY DEMAND BY THE PAPERMILL INDUSTRY (continued)

B. 1976

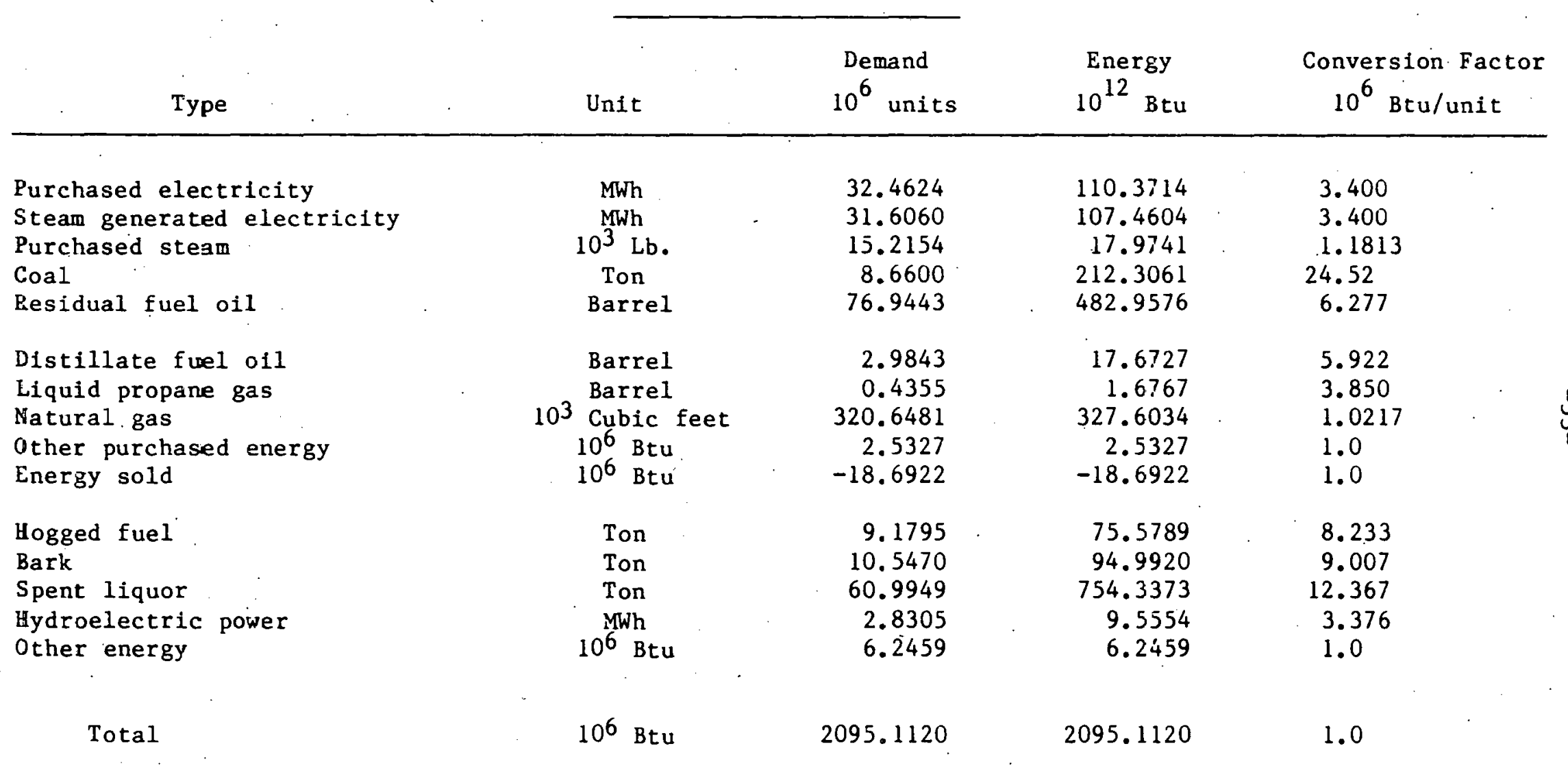

Source: American Paper Institute (10). 
TABLE A-1. ESTIMATED FUEL AND ELECTRICITY DEMAND BY THE PAPERMILL INDUSTRY (continued)

$$
\text { C. } 1975
$$

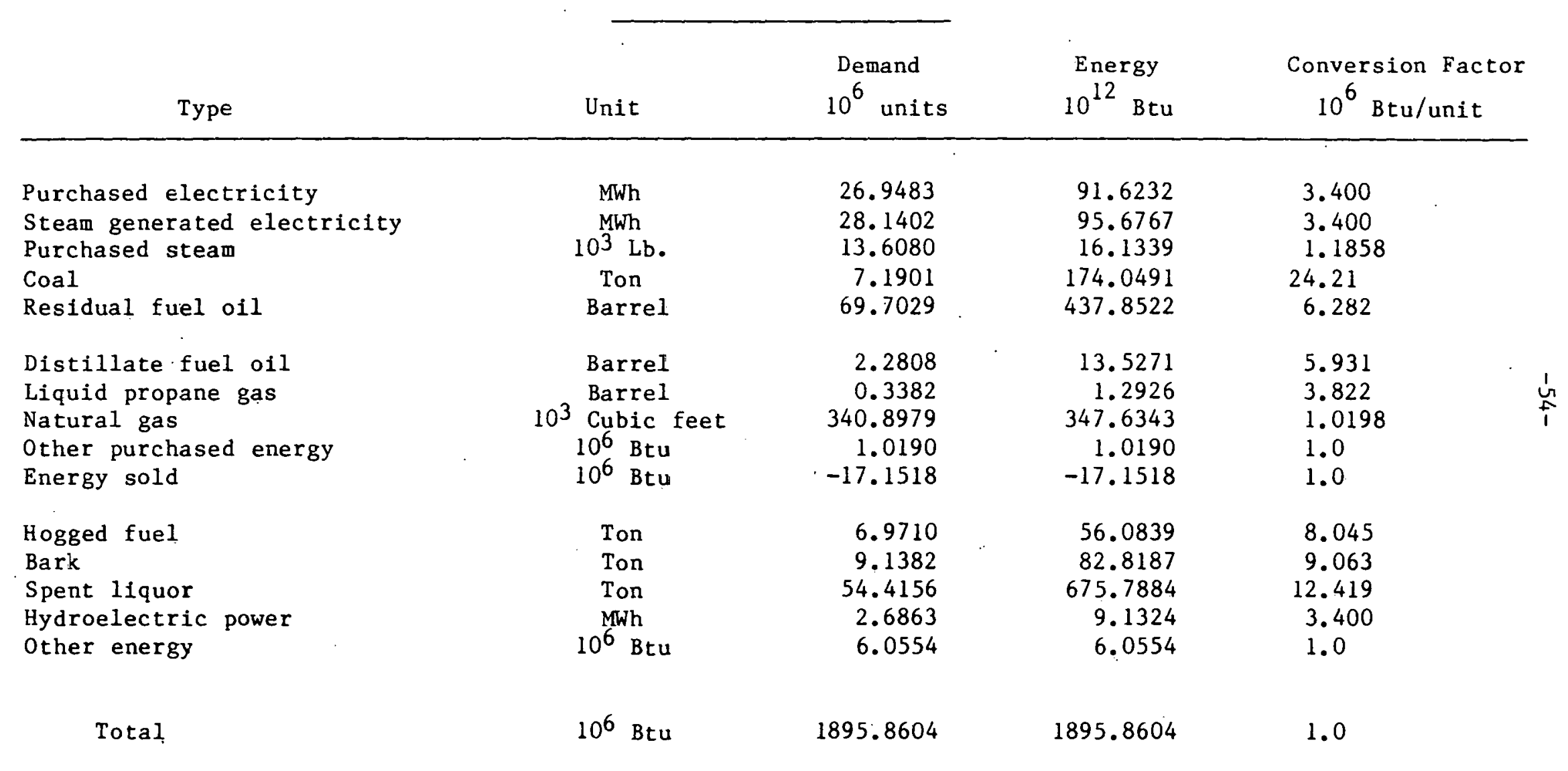

Source: American Paper Institute (10). 
TAELE A-1. ESTIMATED FUEL AND ELECTRICITY DEMAND BY THE PAPERMILL INDUSTRY (continued)

D. 1972

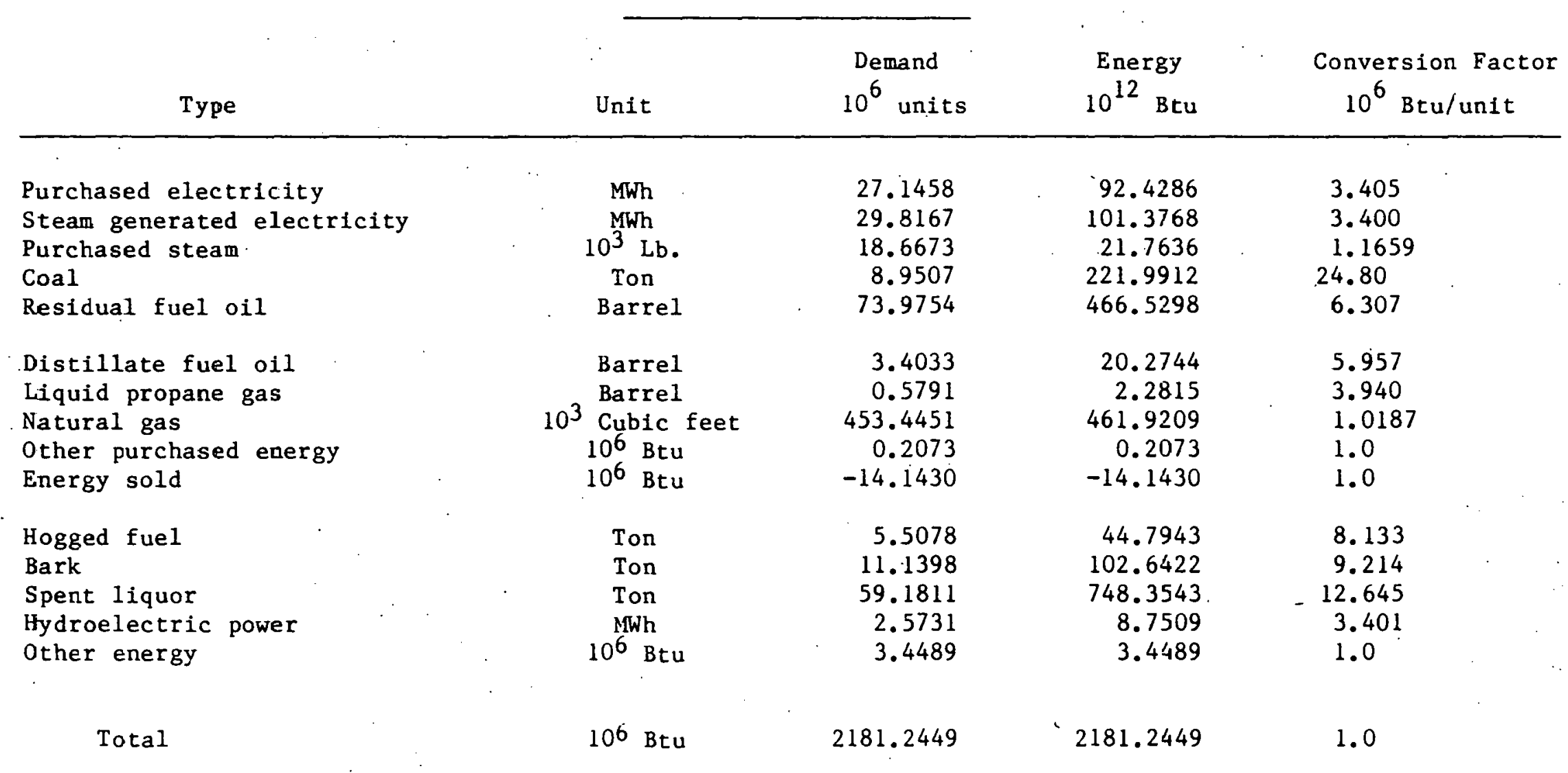

Source: American Paper Institute (10). 
TABLE A-2. ESTIMATED FUEL AND ELECTRICITY DEMAND BY THE PAPER INDUSTRY

\begin{tabular}{|c|c|c|c|c|c|c|}
\hline Year & $\begin{array}{r}\text { Distillate } 0 i l \\
\left(10^{6} \text { barrels }\right)\end{array}$ & $\begin{array}{l}\text { Residual } 011 \\
\left(10^{6} \text { barrels }\right)\end{array}$ & $\left(10^{6}\right.$ tons $)$ & $\begin{array}{l}\text { Natural Ges } \\
\left(10^{3} \text { cubic feet }\right)\end{array}$ & $\begin{array}{c}\text { Purchased } \\
\text { Electricity } \\
(M W h)\end{array}$ & $\begin{array}{c}\text { Generated } \\
\text { Electricity } \\
\text { (MWh) }\end{array}$ \\
\hline 1954 & - & 22.4720 & 12.5720 & 116.6 & 10.8520 & 12.6870 \\
\hline 1958 & - & 25.2850 & 14.4650 & 212.2 & 12.5380 & 16.9780 \\
\hline 1962 & 2.5780 & 28.5270 & 15.1450 & 265.1 & 17.0520 & 21.1650 \\
\hline 1967 & 10.6053 & 31.2941 & 12.9163 & 351.2 & 25.8578 & 23.2114 \\
\hline 1971 & 18.0891 & 46.4995 & 9.4390 & 477.0 & 34.9994 & 25.3843 \\
\hline 1974 & 17.6436 & 56.5554 & 8.4308 & 422.8 & 40.8702 & 27.3832 \\
\hline 1975 & 10.6815 & 70.7726 & 7.4163 & 357.9 & 39.1204 & 24.4326 \\
\hline 1976 & 10.6815 & 70.7726 & 8.4425 & 357.9 & 43.4588 & 25.4874 \\
\hline
\end{tabular}

Source: Bureau of the Census (4): 
TABLE A-3. DEMAND FOR PURCHASED FUEL BY THE PAPER INDUSTRY: COMPARISON OF DATA FROM THE BUREAU OF THE CENSUS AND THE AMERICAN PAPER INSTITUTE

\begin{tabular}{|c|c|c|c|c|c|c|}
\hline \multirow[t]{2}{*}{ - } & \multicolumn{3}{|c|}{1975} & \multicolumn{3}{|c|}{1976} \\
\hline & API & Census & $\begin{array}{c}\text { Ratio } \\
(\%)\end{array}$ & API & Census & $\begin{array}{c}\text { Ratio } \\
(\%)\end{array}$ \\
\hline Distillate oil & 2.2808 & 13.3814 & 17 & 2.9843 & 10.6815 & 28 \\
\hline Residual ofl & 69.7029 & 58.4199 & 119 & 76.9443 & 70.7726 & 109 \\
\hline Fuel ofl & 71.9837 & 71.8013 & 100 & 79.9286 & 81.4541 & 98 \\
\hline Coal & 7.1901 & 7.4163 & 97 & 8.6600 & 8.4425 & 103 \\
\hline Natural gas & 540.8979 & 369.6 & 92 & 320.6481 & 357.9 & 90 \\
\hline Purchased electricity & 26.9483 & 39.1204 & 69 & 32.4624 & 43.4588 & 75 \\
\hline Generated electricity & 30.8265 & 24.4326 & 91 & 34.4365 & 25.4874 & 135 \\
\hline Total electricity & 57.7748 & 63.5530 & 91 & 66.8989 & 68.9462 & 97 \\
\hline
\end{tabular}


product Industry consumes 7 percent of the total.) Disclosure problems prevent precise detailed comparison of all types of fuel, but using the Census data, the papermill industry consumes 86 percent of the distillate fuel oil, 97 percent of the residual fuel o1l, 96 percent of the total fuel o11, 99 percent of the coal, and 89 percent of the natural gas.

Consider Table A-3; there appears to be a definftion problem for distillate and residual fuel ofl. (The definttions appear to have changed several times recently at the Census Bureau.) The API has less distillate and more residual than the Census. There is better agreement on total fuel o11. Based on Census data, we expect the fuel ofl ratio to be 96 percent In 1976; the ratio in Table A-3 is 98 percent, which is in good agreement. We expect the coal ratio to be 99 percent, and we find 103 percent. We expect the natural gas ratio to be 89 percent, and we find 90 percent. Thus, except for the two types of fuel oil, the purchased fuel data are in good agreement.

Using the Census data, the papermill industry consumes 81 percent of the total purchased electricity and produces 100 percent of the total generated electricity. In Table A-3 the papermill 1ndustry purchases 75 percent of the electricity and generates 135 percent of the electricity. The Census total is "generated less sold," while the API total is generated; If we correct for electricity sales of $3.8337 \times 10^{9} \mathrm{kWh}$ (see Table $A-15)$, the papermill industry generates 120 percent of the electricity. Thus, there appears to be a 20-percent difference between API and Census estimates on generated electricity. 
We have chosen the API data as the source for benchmark energy demand totals. Based on the data in Table A-1, Table A-4 provides an estimate of total consumption of fuel by the papermill industry and an estimate of production of energy service in bollers. In 1972, for example, $221.9912 \mathrm{x}$ $10^{12} \mathrm{Btu}$ of coal were consumed in bollers. At an efficiency of 79 percent the coal provided $175.3730 \times 10^{12}$ Btu of energy service.

Some fuel is consumed in lime kilns and other types of furnaces to provide process heat. In Table A-4, we assume that 10 percent of the purchased fuel provides process heat and that the source of process heat is fuel ofl. Thus, the energy service in Table $A^{-4}$ is an estimate of the total energy service provided by boilers.

Tables $A-5, A-6, A-7, A-8$, and $A-9$ are based on information from the Major Fuel Burning Installation (MFBI) data base (13). The MFBI data base is the result of a 1975 questionnalre that was sent by the Federal Energy Administration to all industries that have an MFBI. (An MFBI is a boller or furnace with a design firing rate of more than $100 \times 10^{6} \mathrm{Btu} / \mathrm{hour} \cdot$ ) A discussion of the strengths and weaknesses of the MFBI data base is given by Samuels and Johnson (15).

Table A-5 presents data on fuel consumption and estimates of coverage factors and capacity factors from the MFBI data base. Boiler type is determined by the primary boller fuel. Coal boilers burn primarily coal but also burn a small amount of ofl and gas. Coal is consumed by coal bollers, oll bollers, gas bollers, and other (bark and spent 11quor) bollers. (In the model coal bollers burn coal, and ofl/gas bollers do not burn coal. Thus, the real world is more complex than the model.) 
TABLE A-4. CONSUMPTION OF FUEL AND PRODUCTION OF ENERGY SERVICE BY BOILERS IN THE PAPERMILL INDUSTRY

\begin{tabular}{|c|c|c|c|c|c|}
\hline Fuel Consumption ( $10^{12}$ Btu) & Efficiency & 1972 & 1975 & 1976 & 1977 \\
\hline Coala & & 221.9912 & 174.0491 & 212.3061 & 222.8478 \\
\hline Fuel oilb & & 489.2930 & 453.6909 & 504.8397 & 526.6762 \\
\hline Natural gasa & & 461.9209 & 347.6343 & 327.6034 & 318.1092 \\
\hline Purchased fuel & & 1173.2051 & 975.3743 & 1044.7492 & 1067.6332 \\
\hline Process heat oilc & & 117.3205 & 97.5374 & 104.4749 & 106.7633 \\
\hline Boiler oilc & & 371.9725 & 356.1535 & 400.3648 & 419.9129 \\
\hline Barkd & & 150.8854 & 144.9580 & 176.8168 & 186.2470 \\
\hline Spent liquor ${ }^{a}$ & & 748.3543 & 675.7884 & 754.3373 & 797.0400 \\
\hline Total boiler fuel & & 1955.1243 & 1698.5833 & 1871.4284 & 1944.1569 \\
\hline \multicolumn{6}{|l|}{ Energy Service $\left(10^{12}\right.$ Bᄃu) } \\
\hline $\begin{array}{l}\text { Coal } \\
\text { Boiler oil } \\
\text { Natural gas. } \\
\text { Oil/gas } \\
\text { Bark } \\
\text { Spent liquor }\end{array}$ & $\begin{array}{l}79 \\
83 \\
79 \\
\\
68 \\
60\end{array}$ & $\begin{array}{l}175.3730 \\
308.7372 \\
364.9175 \\
673.6547 \\
102.6021 \\
449.0126\end{array}$ & $\begin{array}{r}137.4988 \\
295.6074 \\
274.6311 \\
570.2385 \\
98.5714 \\
405.4730\end{array}$ & $\begin{array}{l}167.7218 \\
332.3028 \\
258.8067 \\
591.1095 \\
120.2354 \\
452.6024\end{array}$ & $\begin{array}{l}176.0498 \\
348.5277 \\
251.3063 \\
599.8340 \\
126.6479 \\
478.2240\end{array}$ \\
\hline Total & & 1400.6424 & 1211.7817 & 1331.6691 & 1380.7557 \\
\hline
\end{tabular}

aTable $A^{-1}$ is the source of all of the data.

bFuel oll is the sum of residual fuel oil, distillate fuel oil, liquid propane gas, and other purchased energy.

CProcess heat is 10 percent of purchased fuel. Boiler oil is the difference between fuel oil and process heat oil.

$\mathrm{d}_{\text {Bark }}$ is the sum of hogged fuel, bark, and other energy. 
TABLE A-5. CCNSUMPTION OF FUEL, COVERAGE FACTOR, AND CAPACITY FACTORS FROM TFE MAJOR FUEL BURNING INSTALLATION (MFBI) DATA BASE

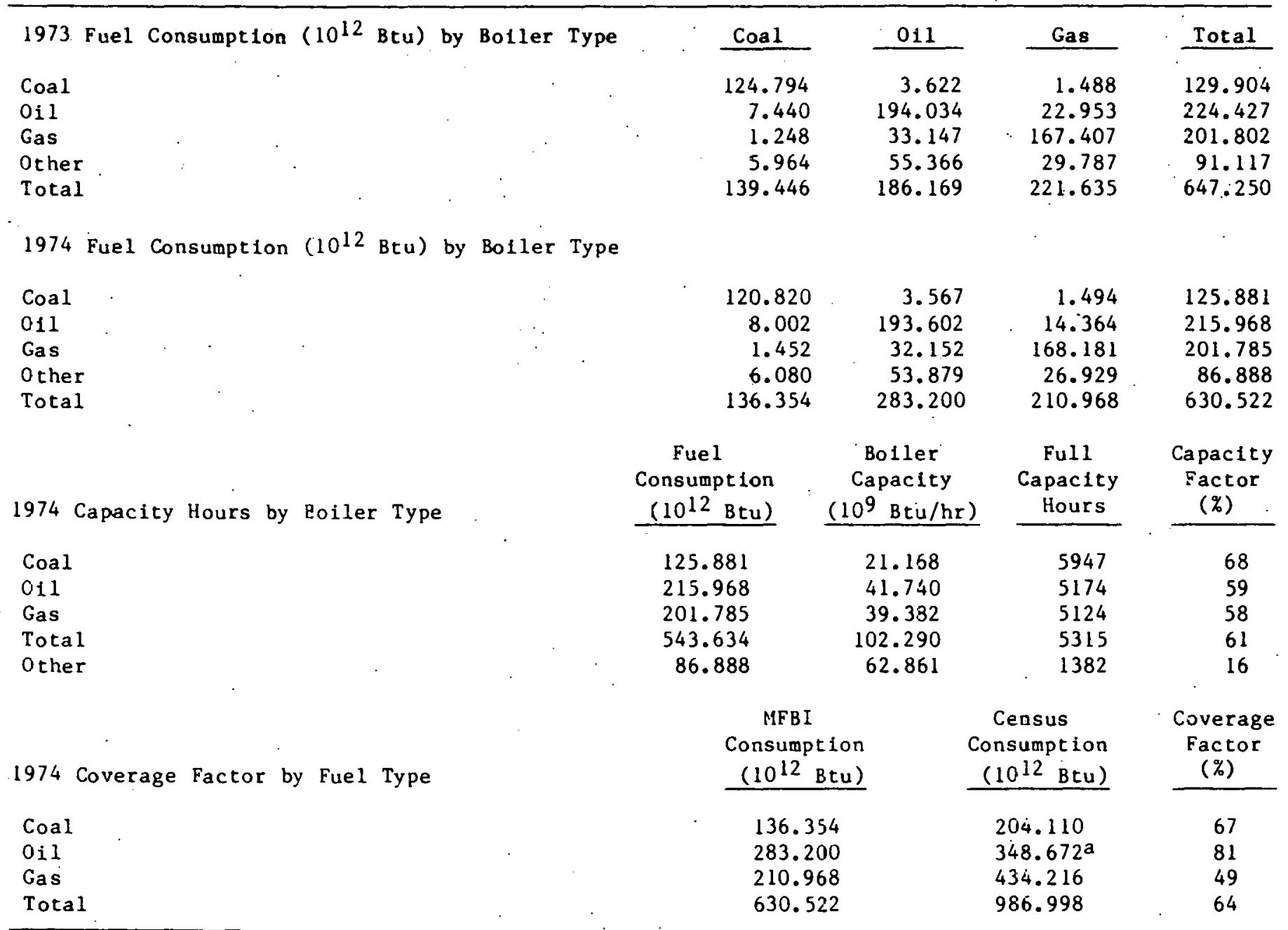

aFuel oll consumed in boilers. $109.666 \times 10^{12}$ Btu of fuel oil have been allocated to process heat consumption (see Table $\mathrm{A}-4$ ).

Source: MFBI data base (13). 
TABLE A-6. CONSUMPTION OF FUEL IN 1974 AND FULL CAPACITY HOURS

Throttle Conditions ${ }^{a}$

\begin{tabular}{lllll}
\hline Unit & A & B & C & D \\
\hline
\end{tabular}

Coal bollers

$\begin{array}{lllrrrr}\text { Coal } & 10^{9} & \text { Btu } & 9280 & 15440 & 30484 & 47504 \\ \text { O11 } & 10^{9} & \text { Btu } & 88 & 0 & 1082 & 2043 \\ \text { Gas } & 10^{9} & \text { Btu } & 0 & 0 & 758 & 64 \\ \text { Total } & 10^{9} & \text { Btu } & 9368 & 15440 & 32324 & 49611 \\ \text { Capacity } & 10^{6} & \text { Btu/hr } & 2090 & 3203 & 3963 & 8715 \\ \text { Hours } & \mathrm{Hr} & & 4482 & 4820 & 8156 & 5693 \\ \text { Factor } & \% & & 51 & 55 & 93 & 65\end{array}$

011 bo1lers

$\begin{array}{lllrrrr}\text { Coal } & 10^{9} & \text { Btu } & 416 & 3426 & 546 & 130 \\ \text { O11 } & 10^{9} & \text { Btu } & 38395 & 37942 & 77880 & 30873 \\ \text { Gas } & 10^{9} & \text { Btu } & 481 & 2545 & 7747 & 3591 \\ \text { Total } & 10^{9} & \text { Btu } & 39292 & 43913 & 86173 & 34594 \\ \text { Capacity } & 10^{6} & \text { Btu/hr } & 7406 & 9186 & 15530 & 7541 \\ \text { Hours } & \mathrm{Hr} & & 5305 & 4780 & 5549 & 4587 \\ \text { Factor } & \% & & 61 & 55 & 63 & 52\end{array}$

Gas bollers

$\begin{array}{lllrrrr}\text { Coal } & 10^{9} & \text { Btu } & 596 & 0 & 24 & 832 \\ \text { O11 } & 10^{9} & \text { Btu } & 10610 & 7837 & 7603 & 3813 \\ \text { Gas } & 10^{9} & \text { Btu } & 57756 & 42304 & 38464 & 25617 \\ \text { Total } & 10^{9} & \text { Btu } & 68962 & 49841 & 46091 & 30262 \\ \text { Capacity } & 10^{6} & \text { Btu/hr } & 15710 & 7718 & 9693 & 5337 \\ \text { Hours } & \mathrm{Hr} & & 4390 & 6458 & 4755 & 5670 \\ \text { Factor } & \% & & 50 & 74 & 54 & 65\end{array}$

Other bollers

$\begin{array}{lllrrrr}\text { Coal } & 10^{9} & \text { Btu } & 0 & 360 & 5720 & 0 \\ \text { O11 } & 10^{9} & \text { Btu } & 6536 & 14223 & 24480 & 4299 \\ \text { Gas } & 10^{9} & \text { Btu } & 3730 & 2133 & 11627 & 8043 \\ \text { Total } & 10^{9} & \text { Btu } & 10266 & 16716 & 41827 & 12342 \\ \text { Capac1ty } & 10^{6} & \text { Btu/hr } & 8340 & 8806 & 28220 & 15472 \\ \text { Hours } & \mathrm{Hr} & & 1231 & 1898 & 1482 & 798 \\ \text { Factor } & \% & & 14 & 22 & 17 & 9\end{array}$

aThrottle conditions defined by the percentage of the boller output that is devoted to electricity generation: A, $0 ; B, 1-10 ; C, 11-20$; and $D$, 21-35.

Source: MFBI data base (13). 
TABLE A-7. CAPACITY FOR COAL BOILERS BY YEAR OF INSTALLATION AND THROTTLE CONDITIONS

MFBI Data $\left(10^{6} \mathrm{Btu} / \mathrm{hr}\right)$

\begin{tabular}{llll}
\hline$A$ & $B$ & $C$ & D
\end{tabular}

$\begin{array}{llll}103 & 103 & 243 & 322 \\ 200 & 130 & 330 & 259 \\ 107 & & 193 & 160 \\ & 103 & & 160\end{array}$

1952
1953

1954

1955

1956

1957

1958

1959

1960

1961

1962

1963

1964

1965

1966

1967

1968

1969

1970

1971

1972

1973

1974

1975

1976

106

188

165

7.56

1144

375

238

110

256

110

165

330

125

378

118

379

370

275

275

Source: MFBI data base (13).

250

1077

295

480
Smoothed MFBI Data $\left(10^{6} \mathrm{Btu} / \mathrm{hr}\right)$

\begin{tabular}{llll}
\hline A & B & C
\end{tabular}

$114 \quad 168$

$116 \quad 185$

$116 \quad 204$

$114 \quad 224$

$111 \quad 245$

45

79

78

$107 \cdot 266$

$104 \quad 288$

$101 \quad 308$

$98 \quad 326$

$96 \quad 341$

$\begin{array}{rrrrr} & 43 & 86 & 95 & 352 \\ 578 & 42 & 90 & 94 & 358 \\ 846 & 42 & 94 & 93 & 358 \\ & 41 & 99 & 93 & 354 \\ & 40 & 102 & 93 & 345\end{array}$

$37 \quad 106$

109

$93 \quad 332$

$94 \quad 315$

$94 \quad 295$

$\begin{array}{lllll}790 & 27 & 114 & 94 & 273\end{array}$

$22 \quad 115$

92

251

$\begin{array}{llll}18 & 116 & 90 & 228\end{array}$

$\begin{array}{lllll}14 & 116 & 87 & \cdot & 207\end{array}$

$\begin{array}{llll}11 & 116 & 83 & 188\end{array}$

$\begin{array}{llll}8 & 115 & 79 & 172\end{array}$

$6 \quad 113 \div 74 \quad 159$

$\begin{array}{llll}4 & 111 & 70 & 150 \\ 2 & 109 & 66 & 144 \\ 2 & 107 & 63 & 140 \\ 1 & 105 & 61 & 138 \\ 1 & 103 & 60 & 137\end{array}$


TABLE A-8. CAPACITY FOR FUEL OIL AND NATURAL GAS BOILERS

\begin{tabular}{|c|c|c|c|c|c|c|c|c|}
\hline & MFBI & \multicolumn{2}{|c|}{ Data $\left(10^{6}\right.$} & $6 \mathrm{Btu} / \mathrm{hr}$ ) & \multicolumn{4}{|c|}{$\begin{array}{l}\text { Smoothed MFBI Data } \\
\left(10^{6} \mathrm{Btu} / \mathrm{hr}\right)\end{array}$} \\
\hline & A & B & $C$ & D & A & B & $\mathrm{C}$ & $\mathrm{D}$ \\
\hline 1947 & & 200 & 1212 & 520 & 118 & 378 & 702 & 194 \\
\hline 1948 & & 1099 & 1518 & 200 & 130 & 396 & 739 & 215 \\
\hline 1949 & 147 & 325 & 1801 & 135 & 146 & 411 & 767 & 237 \\
\hline 1950 & 107 & 514 & 351 & 362 & 166 & 421 & 784 & 258 \\
\hline 1951 & & 396 & 991 & 103 & 192 & 427 & 790 & 278 \\
\hline 1952 & 100 & & 423 & 764 & 223 & 430 & 786 & 297 \\
\hline 1953 & 187 & 338 & 915 & 205 & 261 & 432 & 773 & 315 \\
\hline 1954 & 180 & 760 & 898 & & 307 & 433 & 754 & 332 \\
\hline 1955 & 180 & 370 & 523 & & 361 & 436 & 732 & 349 \\
\hline 1956 & 483 & 1000 & 578 & & 424 & 442 & 709 & 365 \\
\hline 1957 & 358 & & 702 & 905 & 497 & 452 & 687 & 381 \\
\hline 1958 & 347 & & 496 & 1496 & 579 & 468 & 670 & 398 \\
\hline 1959 & 584 & 180 & 340 & 100 & 671 & 488 & 658 & 416 \\
\hline 1960 & 383 & & 1112 & & 769 & 513 & 652 & 437 \\
\hline 1961 & 613 & 433 & & & 871 & 539 & 653 & 459 \\
\hline 1962 & 145 & 799 & 632 & 210 & 973 & 566 & 662 & 485 \\
\hline 1963 & 719 & 867 & 342 & & 1072 & 589 & 676 & 511 \\
\hline 1964 & 1846 & 890 & 160 & 459 & 1161 & 607 & 694 & 539 \\
\hline 1965 & 2455 & 592 & 950 & 1360 & 1238 & 618 & 714 & 565 \\
\hline 1966 & 786 & 958 & 989 & 388 & 1299 & 620 & 733 & 589 \\
\hline 1967 & 2766 & 1513 & 769 & 1058 & 1344 & 615 & 750 & 609 \\
\hline 1968 & 1096 & 293 & 603 & 335 & 1372 & 603 & 763 & 623 \\
\hline 1969 & 1699 & 175 & 973 & 1426 & 1386 & 587 & 771 & 633 \\
\hline 1970 & 1265 & 596 & 2082 & 421 & 1390 & 569 & 773 & 637 \\
\hline 1971 & 684 & 179 & & & 1387 & 551 & 770 & 638 \\
\hline 1972 & 771 & 149 & 1198 & 1281 & 1380 & 536 & 764 & 636 \\
\hline 1973 & 740 & 442 & & 178 & 1372 & 524 & 755 & 633 \\
\hline $\begin{array}{l}1974 \\
1975\end{array}$ & 1471 & 491 & 167 & .196 & $\begin{array}{l}1363 \\
1352^{\circ}\end{array}$ & $\begin{array}{l}515 \\
508\end{array}$ & $\begin{array}{l}745 \\
734\end{array}$ & $\begin{array}{l}629 \\
623\end{array}$ \\
\hline 1976 & & & & & 1338 & 501 & 721 & 616 \\
\hline
\end{tabular}

Source: MFBI data base (13). 
TABLE A-9. CAPACITY FOR OTHER (BARK AND SPENT LIQUOR) BOILERS

$\begin{array}{cccc}\text { MFBI Data }\left(10^{6} \mathrm{Btu} / \mathrm{hr}\right) \\ \text { A } & \text { B } & \text { C } & \text { D }\end{array}$

Smoothed MFBI Data $\left(10^{6} \mathrm{Btu} / \mathrm{hr}\right)$

\begin{tabular}{llll}
\hline$A$ & $B$ & $C$ & $D$ \\
\hline
\end{tabular}

\begin{tabular}{|c|c|c|c|c|c|c|c|c|}
\hline 1947 & & 101 & 446 & 489 & 22 & 87 & 354 & 201 \\
\hline 1948 & & 532 & 498 & 169 & 25 & 97 & 411 & 222 \\
\hline 1949 & & 130 & 556 & 760 & 30 & 106 & 468 & 241 \\
\hline 1950 & & & 705 & 192 & 36 & 115 & 526 & 258 \\
\hline 1951 & & & 1149 & & 44 & 124 & 584 & 273 \\
\hline 1952 & & & & 748 & 53 & 132 & 641 & 286 \\
\hline 1953 & & & 494 & & 65 & 142 & 697 & 298 \\
\hline 1954 & 340 & 397 & 557 & & 78 & 153 & 752 & 309 \\
\hline 1955 & & 150 & 263 & & 94 & 166 & 806 & 320 \\
\hline 1956 & & 236 & 765 & 586 & 113 & 181 & 859 & 332 \\
\hline 1957 & & & 1701 & & 134 & 199 & 911 & 344 \\
\hline 1958 & & 123 & 1205 & 1084 & 159 & 219 & 962 & 359 \\
\hline 1959 & 268 & & 1881 & 560 & 187 & 243 & 1012 & 377 \\
\hline 1960 & & 276 & & 317 & 218 & 269 & 1060 & 399 \\
\hline 1961 & 379 & & 707 & & 253 & 298 & 1107 & 426 \\
\hline 1962 & 190 & 600 & 318 & & 290 & 328 & 1152 & $459^{\circ}$ \\
\hline 1963 & 324 & 686 & 782 & & 330 & 361 & 1194 & 498 \\
\hline 1964 & 158 & 338 & 2361 & & 373 & 394 & 1232 & 542 \\
\hline 1965 & 750 & 108 & $\begin{array}{r}670 \\
2095\end{array}$ & $\begin{array}{r}480 \\
\end{array}$ & 416 & $\begin{array}{l}428 \\
461\end{array}$ & $\begin{array}{l}1264 \\
1290\end{array}$ & 590 \\
\hline 1966 & & 464 & 2095 & 1210 & 458 & 461 & 1290 & 641 \\
\hline 1967 & 200 & 297. & 2600 & 1954 & 499 & 491 & 1309 & 693 \\
\hline 1968 & 750 & & 655 & 408 & 538 & 519 & 1323 & 744 \\
\hline 1969 & 631 & 997 & 520 & & 572 & 543 & 1331 & 791 \\
\hline 1970 & 538 & & 1453 & & 601 & 561 & 1335 & 834 \\
\hline 1971 & 1603 & 2249 & 731 & 675 & 623 & 572 & 1337 & 870 \\
\hline 1972 & 210 & 865 & 1340 & 2229 & 639 & 577 & 1337 & 899 \\
\hline 1973 & 701 & & 971 & 1777 & 647 & 577 & 1334 & 919 \\
\hline 1974 & 505 & 108 & 1820 & 108 & 649 & 570 & 1329 & 930 \\
\hline 1975 & & & & & 644 & 559 & 1319 & 932 \\
\hline 1976 . & & & & & 634 & 544 & 1302 & 924 \\
\hline
\end{tabular}

Source: MFBI data base (13). 
In 1974 the average capacity factor for the purchased-fuel bollers was 61 percent, and the range was 58 percent to 68 percent. The capactity factor for the other bollers is low (16 percent) because the MFBI data base does not include consumption of other fuel (bark and spent 11quor).

Comparing data from the MFBI and the Census, the 1974 coverage factor 1864 percent, with a range from 49 percent to 81 percent: We expect coal boilers to be large and gas bollers to be small, with oil in between. Thus, the low coverage factor for gas is reasonable. However, we would expect a higher coverage factor for coal than for o1l. The ofl total has been reduced by $109.666 \times 10^{12} \mathrm{Btu}$ to correct for process heat. If we use the original fuel ofl consumption, the coverage factor for fuel ofl becomes 62 percent. Since the lower coverage factor for ofl is more reasonable, perhaps our assumption that ofl is the process heat fuel is incorrect. However, if we decrease the boller consumption of natural gas and increase the consumption of fuel ofl, the average coverage factor will be unchanged, and the only change in our estimate for boller energy service in Table $A-4$ will be caused by the differences in efficiency ( 79 percent for natural gas and 83 percent for fuel o11.)

Table A- 6 presents data on fuel consumption and capacity factors for four types of throttle conditions. (For the MFBI data, throttle conditions are defined by the percentage of the boller output that 1 t devoted to electricity generation.) The data does not appear to have a consistent pattern. Some of the data may be in error; for example, the capacity factor for coal-C is too high, and the capacity factor for natural gas-B may be too high. 
Tables A-7, A-8, and A-9 present capacity data for coal, o1l/gas, and other bollers by year of installation and by type of throttle conditions. The data are presented as direct MFBI data and as smoothed MFBI data. The impact of smoothing the MFBI data is shown in Figure A-1. The MFBI data varies from large positive numbers to zero from one year to the next. The MFBI data was smoothed by replacing each data point by a normal distribution with a standard deviation of 5 years and an area equal to the magnitude of the data point. The boller capacity. in each year is obtained by adding the contributions from all of the distribution functions. The smoothed MFBI data is an input for the Penetration Model.

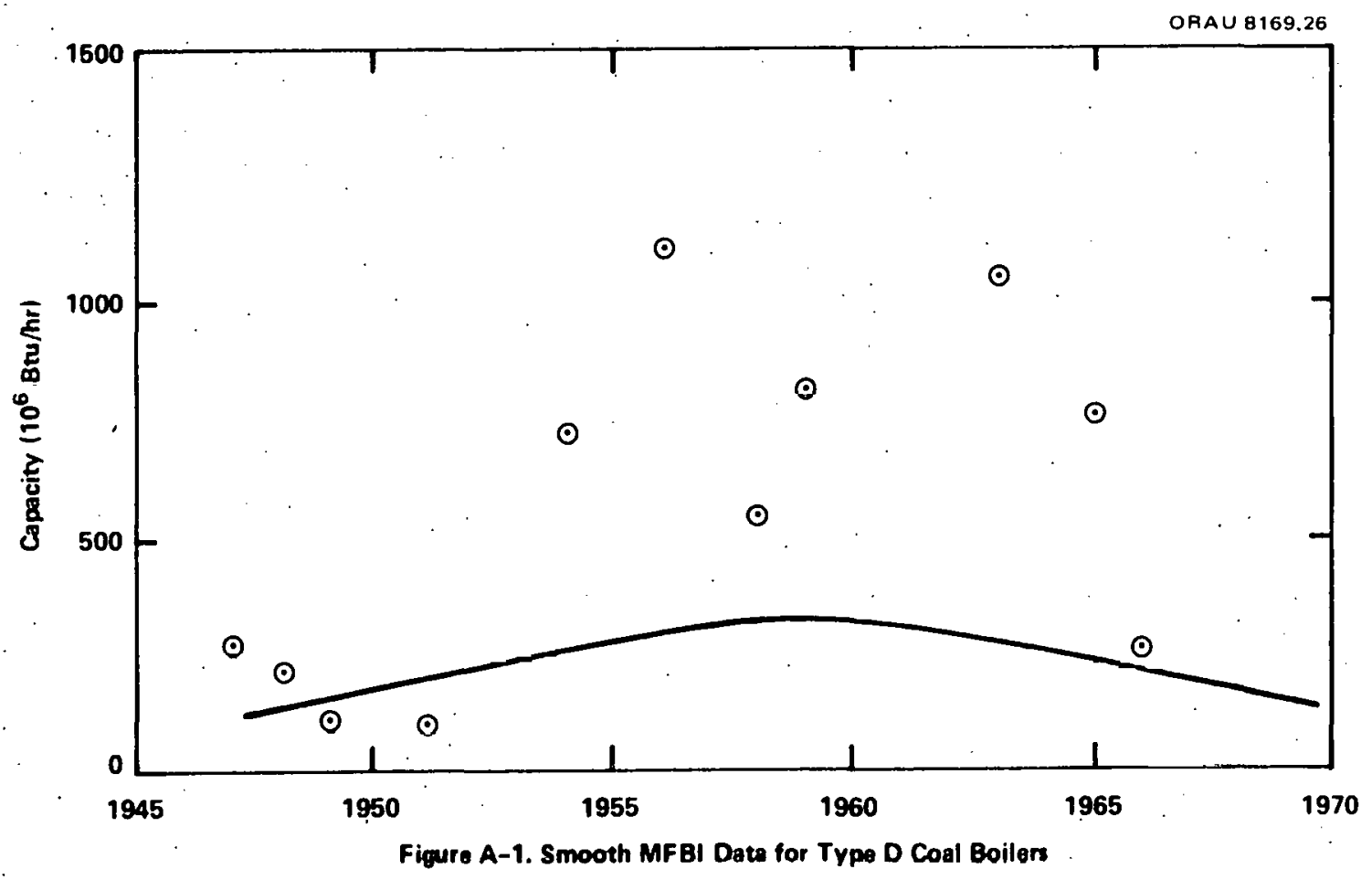


Table A-10 presents data on capacity by fuel type and throttle cond1tions for botlers ordered from 1965 to 1977 . The data source is the American Botler Manufacturers Association (ABMA)(11). The data coverage Includes MFBI bollers and small bollers.

Table A-11 presents a comparison of the MFBI data and ABMA data. The MFBI data is in units of millions of Btu per hour, whtlp the original ABMA data is in units of millions of pounds of steam per hour. To convert from puunds to $\mathrm{BCu}$, we have used the converston factors shown in part $\mathrm{E}$ of $\mathrm{Table}$ A-11. The conversion factors were derived using the Major Botler Model. The conversion factors increase with throttle conditions, since more electric1ty is produced, and increase with decreasing fuel conversion efficlency. Recall that oil has the highest efficiency ( 83 percent), while spent liquor has the lowest efficiency ( 60 percent).

Throttle conditions have different definitions for the two sets of data. The throttle conditions are given for the ABMA data. The throttle conditions for the MFBI data are based on the fraction of the boller output devoted to electricity. An ABMA boiler with low throttle conditions (type A) and a condensor could have high electricity production.

Compare parts $A$ and $C$ of Table A-11: the total fuel demand for o1l/ gas bollers reported by ABMA is lower than the total for MFBI, but the ABMA has more type A bollers than the MFBI. The MFBI has only large botlers, while the ABMA has all bollers ordered in a 13-year period. The o1l/gas type A bollers that are smaller than MFBI slze would appear in the ABMA data but not in the MFBI data. The total fuel demand by coal bollers in 
TABLE A-10. CAPACITY BY FUEL TYPE AND THROTTLE CONDITIONS FOR BOILERS ORDERED FROM 1965 TO 1977

A. Capacity by Fuel Type $\left(10^{6} \mathrm{lb} / \mathrm{hr}\right)$

Fuel Type

\begin{tabular}{cccccc}
$\begin{array}{c}\text { Throttle } \\
\text { Conditions }\end{array}$ & O11/Gas & Coal & Spent Liquor & Bark & Total \\
\hline A & 27.29 & 1.43 & 23.01 & 11.38 & 63.11 \\
B & 10.14 & 1.72 & 15.47 & 1.37 & 28.70 \\
C & 11.52 & 3.12 & 16.83 & 5.63 & 37.10 \\
D & 2.34 & 3.19 & 1.62 & 0.30 & 7.45 \\
Tota1 & 51.29 & 9.46 & 56.93 & 18.68 & 136.36
\end{tabular}

B. Defintions of Normal Throttle Conditions

\begin{tabular}{cccc} 
Type & $\begin{array}{c}\text { Pressure } \\
(\text { psig) }\end{array}$ & $\begin{array}{c}\text { Temperature } \\
\left({ }^{\circ} \mathrm{F}\right)\end{array}$ & $\begin{array}{c}\text { Enthalpy } \\
\text { Categories }\end{array}$ \\
\hline A & 185 & 450 & $1-8$ \\
B & 600 & 750 & 9 \\
C & 900 & 825 & 10 \\
D & 1250 & 900 & 11
\end{tabular}

Source: ABMA data (11). 
TABLE A-11. COMPARISON OF MFBI AND ABMA ESTIMATES OF CAPACITY BY FUEL TYPE AND THROTTLE CONDITIONS

Throttle

Fue1 Type

Conditions

A. MFBI $\left(10^{6} \mathrm{Btu} / \mathrm{hr}\right)$
A

B

C

D

Total

$011 /$ Gas

Coal

23116
16904
25223
12878
78121

B. $\mathrm{MFBI}(\%)$

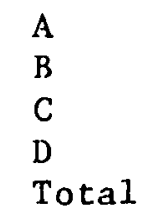

C. ABMA $\left(10^{6} \mathrm{Btu} / \mathrm{hr}\right)$

$\begin{array}{lr}\text { A } & 30806 \\ \text { B } & 13151 \\ \text { C } & 25385 \\ \text { D } & 3286 \\ \text { Total } & 62628\end{array}$

D. ABMA (\%)

$\begin{array}{lr}\text { A } & 15 \\ \text { B } & 6 \\ \text { C } & 7 \\ \text { D } & 2 \\ \text { Total } & 30\end{array}$

15
11
16
8

1651
2294
4278
4498
12721

53546

31517

41771

3731

130565
Total

33546

28913

57406

37065

156930

21
18
37
24
100

86003

46962

61434

11515

205914

E. ABMA conversion factors (Btu/1b of steam)

\begin{tabular}{lcccc} 
& O11 & Gas/Coal & Bark & $\begin{array}{c}\text { Spent } \\
\text { L1quor }\end{array}$ \\
\cline { 2 - 5 } A & 1098.7 & 1154.4 & 1341.1 & 1663.8 \\
B & 1269.2 & 1333.5 & 1549.2 & 1900.1 \\
C & 1304.9 & 1371.0 & 1592.8 & 1949.1 \\
D & 1342.0 & 1409.9 & 1638.0 & 1999.9
\end{tabular}

F. Boller fuel shares (\%)

\begin{tabular}{ccc}
$011 /$ Gas & Coal & Other \\
\hline 43 & 11 & 46 \\
41 & 10 & 48 \\
39 & 11 & 50 \\
38 & 11 & 51
\end{tabular}


the ABMA data is smaller than the demand in the MFBI data for all types of bollers. For other bollers the ABMA reports more than twice the capacity of the MFBI, and there are six times as many type A bollers in the ABMA data.

Compare parts B, D, and F of Table A-11: for the MFBI, 50 percent of the capacity 1s o1l/gas; for the AMBA, 30 percent of the capacity is o1l/ gas; the actual fuel share for of/gas decreased from 43 percent to 38 percent in the pertod from 1972 to 1977. Similarly for "other" boilers the MFBI is lower than the fuel shares and the ABMA is higher than the fuel shares.

The ofl/gas boller data from both the MFBI and ABMA appears to be reasonable. Other bollers are primarily spent liquor bollers, and spent 11quor bollers tend to be large (the average size is $340,0001 \mathrm{~b} / \mathrm{hr}$ ). Thus, spend liquor bollers are MFBIs and should be part of the MFBI data base. If the oll/gas data is approximately correct, there are too few "other" boilers in the MFBI data and too many in the ABMA data. Other bollers have a shorter lifetime than o1l/gas or coal bollers, and the fuel consumption In other bollers has been 1ncreasing. Thus, the ABMA data seems reasonable; but the MFBI data appears to have too few other bollers.

We assume that the MFBI data (Tables A-7, A-8, and A-9) gives the correct age distribution for the stock of bollers and that the ABMA data (Table A-10) gives the correct throttle condition distribution for the boiler stock. To match the control totals for energy service and generated electricity (provided by Tables $A-1$ and $A-4$ ), we need to choose a typical 
representative from each of the 16 classes of bollers and use the Major Boller Model to calculate $I-0$ coefficients. The nominal throttle conditions are given in Table $A-10$, and the boller $I-0$ coefficients are given in Table A-12. Using the boller $I-0$ coefficlents in Table $A-12$, the estimates of capacity and process steam production are given in Tables A-13 and A-14. Table A-12 presents the results of the Major Boller Model for d itcovery boller and a combination (bark, coal, oil/gas) boiler for four types of throttle conditions. Both the spent liquor and combination bollers provide the same amount of process steam $(953,0001 \mathrm{~b} / \mathrm{hr})$ for all four types of throttle conditions. The combination boller has one feedwater heater and requires more high-pressure steam from the boller per unlt of process steam than the spent liquor boller, but as a consequence the combination boller produces more electricity and requires less energy service than 'the spent ' liquor boiler. Thus, the combination boller with one feedwater heater is more efficient than a spent liquor boller without a feedwater heater.

The saturated bollers (type A) do not produce electriclty. The superheated boflers produce electrictiy, and the amount increases with an increase in throttle conditions. The superheated systems produce electricity very effictently. Compared to the saturated bollers, the differential heat rates for the superheated systems range from 3,464 to 3,448 Btu of energy service per $\mathrm{kWh}$ of electricity. The energy service efficiencies range from 98.53 percent to 98.99 percent. (We assume a turbine efficlency of 98.5 . percent. The differential energy service efficlencles are higher than the turbine efficiencies because higher throttle conditions improve system performance.) 
TABLE A-12. RESULTS OF THE MAJOR BOILER MODEL FOR A RECOVERY BOILER AND A COMBINATION BOILER

Throttle Conditions

\begin{tabular}{llllll}
\cline { 2 - 4 } Symbol & Anits & A & B & C & D
\end{tabular}

Spent Liquor Recovery Boiler

Boiler steam output

Boiler energy service input

Process steam demand

Electric power output

Steam ratio

Power ratio

Energy ratio

Heat rate

$\begin{array}{clrrrr}\mathrm{M} & 10^{3} \mathrm{lb} / \mathrm{hr} & 1000 & 987 & 992 & 992 \\ \mathrm{U} & 10^{6} \mathrm{Btu} / \mathrm{hr} & 999 & 1125 & 1160 & 1191 \\ \mathrm{Q} & 10^{3} \mathrm{lb} / \mathrm{hr} & 953 & 953 & 953 & 953 \\ \mathrm{P} & \mathrm{MW} & 0 & 36.5 & 46.7 & 55.7 \\ \mathrm{M} / \mathrm{Q} & 1 \mathrm{~b} / \mathrm{lb} & 1.049 & 1.035 & 1.041 & 1.041 \\ \mathrm{P} / \mathrm{Q} & \mathrm{kWh} / 10^{3} \mathrm{lb} & 0 & 38.3 & 49.0 & 58.5 \\ \mathrm{U} / \mathrm{Q} & \mathrm{Btu} / \mathrm{lb} & 1048 & 1180 & 1217 & 1249 \\ \Delta \mathrm{U} / \Delta \mathrm{P} & \mathrm{Btu} / \mathrm{kWh} & -- & 3464 & 3457 & 3448\end{array}$

Bark, Coal, 01:/Gas Boiler

Boiler steam output

Boiler energy service input

Process steam demand

Electric power output

Steam ratio

Power ratio

Energy ratio

Heat rate

$\begin{array}{clrrrr}\mathrm{M} & 10^{3} \mathrm{lb} / \mathrm{hr} & 1072 & 1054 & 1060 & 1060 \\ \mathrm{U} & 10^{6} \mathrm{Btu} / \mathrm{hr} & 978 & 1110 & 1148 & 1181 \\ \mathrm{Q} & 10^{3} \mathrm{lb} / \mathrm{hr} & 953 & 953 & 953 & 953 \\ \mathrm{P} & \mathrm{MW} & 0 & 38.2 & 49.2 & 58.8 \\ \mathrm{M} / \mathrm{Q} & 1 \mathrm{~b} / 1 \mathrm{~b} & 1.125 & 1.106 & 1.112 & 1.113 \\ \mathrm{P} / \mathrm{Q} & \mathrm{kWh} / 10^{3} \mathrm{lb} & 0 & 40.1 & 51.6 & 61.7 \\ \mathrm{U} / \mathrm{Q} & \mathrm{Btu} / \mathrm{lb} & 1026 & 1165 & 1204 & 1239 \\ \Delta \mathrm{U} / \Delta \mathrm{P} & \mathrm{Btu} / \mathrm{kWh} & - & 3463 & 3460 & 3455\end{array}$


TABLE A-13. BASE YEAR (1976) ACCOUNTS BY FUEL TYPE AND THROTTLE CONDITIONS

Spent

Liquor

Bark

Coal

$011 /$ Gas

Total

Capacity $\left(10^{6} \mathrm{lb} / \mathrm{hr}\right)$

$\begin{array}{lrrrrr}\text { A } & 31.7 & 14.3 & 4.5 & 60.7 & 111.2 \\ \text { B } & 21.3 & 1.7 & 5.4 & 22.5 & 51.0 \\ \text { C } & 23.2 & 7.1 & 9.8 & 25.6 & 65.7 \\ \text { D } & 2.2 & 0.4 & 10.0 & 5.2 & 17.8 \\ \text { Total } & 78.6 & 23.5 & 29.7 & 114.0 & 245.8\end{array}$

Process steam $\left(10^{9} 1 \mathrm{~b} / \mathrm{yr}\right)$

$\begin{array}{lrrrrr}\text { A } & 156.1 & 65.7 & 20.6 & 278.2 & .520 .5 \\ \text { B } & 110.0 & 8.3 & 26.1 & 108.9 & 253.2 \\ \text { C } & 119.1 & 34.0 & 47.1 & 122.9 & 323.0 \\ \text { D } & 11.5 & 1.8 & 48.1 & 25.0 & 86.3 \\ \text { Total } & 396.6 & 109.8 & 141.8 & 534.9 & 1183.1\end{array}$

Nominal capacity factor $(\mathrm{hr} / \mathrm{yr})$

$\begin{array}{llllll}\text { A } & 4915 & 4586 & 4586 & 4586 & 4680 \\ \text { B } & 5155 & 4826 & 4826 & 4826 & 4964 \\ \text { C } & 5128 & 4799 & 4799 & 4799 & 4915 \\ \text { D } & 5126 & 4797 & 4797 & 4797 & 4838 \\ \text { Total } & 5049 & 4671 & 4771 & 4691 & 4813\end{array}$

Generated electricity $\left(10^{9} \mathrm{kWh} / \mathrm{yr}\right)$

$\begin{array}{lrrrrr}\text { A } & 0 & 0 & 0 & 0 & 0 \\ \text { B } & 4.21 & 0.33 & 1.05 & 4.37 & 9.96 \\ \text { C } & 5.83 & 1.75 & 2.43 & 6.34 & 16.36 \\ \text { D } & 0.67 & 0.11 & 2.97 & 1.54 & 5.29 \\ \text { Total } & 10.72 & 2.20 & 6.44 & 12.25 & 31.61\end{array}$

Demand for energy service $\left(12^{12} \mathrm{Btu} / \mathrm{yr}\right)$

$\begin{array}{lrrrrr}\text { A } & 163.5 & 67.4 & 21.1 & 285.4 & 537.4 \\ \text { B } & 129.9 & 9.7 & 30.4 & 126.7 & 296.7 \\ \text { C } & 144.9 & 40.9 & 56.6 & 148.0 & 390.6 \\ \text { D } & 14.3 & 2.2 & 59.6 & 30.9 & 107.0 \\ \text { Total } & 452.6 & 120.2 & 167.7 & 591.1 & 1331.7\end{array}$


TABlE A-14. TOTAL CAPACITY, TOTAL PRODUCTION OF PROCESS STEAM, AND FULL CAPACITY HOURS FOR 1972, 1975, 1976, AND 1977

CAPACITY, PROCESS STEAM, AND HOURS

\begin{tabular}{|c|c|c|c|c|c|c|}
\hline & $\begin{array}{c}\text { Total } \\
\text { Capacity } \\
\left(10^{6} \mathrm{lb} / \mathrm{hr}\right)\end{array}$ & $\begin{array}{c}\text { Total } \\
\text { Process Steam } \\
\left(10^{9} \mathrm{lb} / \mathrm{yr}\right)\end{array}$ & $\begin{array}{l}\text { Power Ratio } \\
(\mathrm{kWh} / 1000 \mathrm{lb})\end{array}$ & $\begin{array}{l}\text { Average } \\
(\mathrm{hr} / \mathrm{yr})\end{array}$ & $\begin{array}{l}\text { Saturated } \\
(\mathrm{hr} / \mathrm{yr})\end{array}$ & $\begin{array}{l}\text { Superheated } \\
(\mathrm{hr} / \mathrm{yr})\end{array}$ \\
\hline 1972 & 261.2 & 1256.3 & 23.7 & 5256 & 5937 & 4700 \\
\hline 1975 & 224.2 & 1078.8 & 26.1 & 5256 & 5254 & 5258 \\
\hline 1976 & 245.8 & 1183.1 & 26.7 & 5256 & 5159 & 5337 \\
\hline 1977 & 254.2 & 1224.1 & 27.4 & 5256 & 50014 & 5464 \\
\hline
\end{tabular}

TOTAL OAPACITY BY FUEL TYPE FOR 1972, 1975, 1976, AND $1977\left(10^{6} \mathrm{lb} / \mathrm{hr}\right)$

Percent

\begin{tabular}{|c|c|c|c|c|c|c|c|c|c|}
\hline \multirow{2}{*}{\multicolumn{2}{|c|}{$\begin{array}{l}\text { Spent } \\
\text { Liquor } \\
\end{array}$}} & \multirow[b]{2}{*}{ Bark } & \multirow[b]{2}{*}{ Coal } & \multirow[b]{2}{*}{$0 i 1 /$ Gas } & \multirow[b]{2}{*}{ Total } & \\
\hline & & & & & & $\begin{array}{l}\text { Spent } \\
\text { Liquor }\end{array}$ & Bark & Coal & $0 i 1 /$ Gas \\
\hline 1972 & 79.7 & 19.4 & 34.0 & 128.5 & 261.6 & 30 & 7 & 13 & 49 \\
\hline 1975 & 70.6 & 19.2 & 24.6 & 109.9 & 224.2 & 31 & 9 & 11 & 49 \\
\hline 1976 & 78.6 & 23.5 & 29.7 & 114.0 & 245.8 & 32 & 10 & 12 & 46 \\
\hline 1977 & 82.6 & 24.9 & 30.7 & 116.0 & 254.2 & 33 & 10 & 12 & 46 \\
\hline
\end{tabular}

TOTAL CAPAIITY BY THROTTLE CONDITIONS FOR 1972, 1975, 1976, AND $1977\left(10^{6}\right.$ lb/hr $)$

\begin{tabular}{cccccccccc} 
& A & B & C & D & Total & A & B & C & D \\
\cline { 2 - 8 } 1972 & 117.5 & 54.7 & 69.5 & 19.9 & 261.6 & 45 & 21 & 27 & 8 \\
1975 & 102.4 & 46.8 & 59.4 & 15.6 & 224.2 & 46 & 21 & 27 & 7 \\
1976 & 111.2 & 51.0 & 65.7 & 17.8 & 245.8 & 45 & 21 & 27 & 7 \\
1977 & 114.9 & 52.8 & 68.1 & 18.4 & 254.2 & 45 & 21 & 27 & 7
\end{tabular}


Given the energy service heat rate, the fuel heat rate is computed using the combustion efflclency of fuel. For example, suppose coal is burned with an efficlency of 79 percent in a type C boller with an energy service heat rate of $3,460 \mathrm{Btu} / \mathrm{kWh}$. The energy service efficiency of 98.64 percent multiplied by the coal combustion efficiency of 79 percent yields a system efficlency of 77.93 percent and a heat rate of $4,380 \mathrm{Btu} / \mathrm{kWh}$, which is much better than the $11,000 \mathrm{Btu} / \mathrm{kWh}$ heat rate for delivered utility electricity.

Table A-13 presents the base year energy accounts. For the base year the amount of-process steam produced by each process, $x_{j}(t)$, is the product of the capacity for each process, $z_{j}(t)$, and the nominal capacity factor, $H_{j}(t)$ :

$$
X_{j}(t)=H_{j}(t) \cdot Z_{j}(t) ; j=1,16 .
$$

Capacity is measured in pounds of steam from the boller, which is greater than the amount of process steam. Thus, the nominal capacity factor is equal to the quotient of the number of full capacity hours of boller operation, $H_{j}^{f}(t)$, and the steam ratio, $\eta_{j}$; that is,

$$
H_{j}(t)=H_{j}^{f}(t) / n_{j} ; \quad j=1,16 .
$$

The values of the steam ratio in Table A-12 range from 1.035 for. a type $B$ recovery boller to 1.125 for a type A combination boller. 
The total demand for factor 1 by all bollers, $Y_{1}(t)$, is determined by summing over all bollers the product of the output of process steam and the $I-0$ coefficient, $a_{1 j}$; that is,

$$
Y_{1}(t)=\sum_{j} a_{i j} X_{j}(t) ; \quad 1=1,7 \text {. }
$$

The first five factors are (1) spent liquor service, (2) bark service, (3) coal service, (4) oll/gas service, and (5) electricity. For the base year (1976), the total amounts of the first five factors are given in Tables $A-1$ and $A-4$. The $I-0$ coefficients and steam ratios are given in Table A-12. The unknowns are the number of full capac1ty hours for each process and the capacity for each process. There are 32 unknowns to be determined by five conditions. To solve the system, 27 additional conditions are required.

Estimates of full capacity hours from the MFBI data base are presented In Tables $A-5$ and $A-6$. For purchased fuel boflers the average capacity factor was 61 percent in 1974. Although the data in Table A-6 could provide a basis for estimating full capacity hours, we decided the data was too unreliable. We assume the average capacity factor for the base year was 60 percent, that is, 5,256 full capacity hours per year. We assume that the superheated bollers (types B, C, and D) have the same capacity factor and allow $1 t$ to differ from the capacity factor for saturated botlers (type A). Thus, the 16 possible values for the number of full capactity hours are reduced to two, and the average value is constratned, 
resulting in one degree of freedom to determine the number of full capacity hours for each process.

Our estlmate of the capacity for each process could be based on the MFBI data base or on the ABMA data base. We have chosen the ABMA data base because the data seem more rellable and the coverage 18 more complete. We use the ABMA data in Table A-10 to determine the mix of throttle conditions for each fuel type but vary the magnitude to match the control total for each type of energy service given in Table $A-4$.

Compare part $A$ of Tables $A-10$ and A-13. The total capacity increases from 136 to 246, less than a factor of two. Coal capacity almost triples, while ofl/gas capacity doubles; capacity of spent liquor and bark bollers Increases by about 35 percent.

To summarize, the ABMA data determines the mix of throttle conditions. The magnitude of the capacity by type of energy service is determined by the control totals on demand for energy service. The relative number of full capacity hours for saturated and superheated bollers is determined by the control total on generation of electricity.

Table A-13 presents the detafled energy accounts for the base year. Fur each process the table presents an estimate of capacity, process steam production, nominal capacity factor, generation of electricity, and demand for energy service.

Table A-14 presents a summary of the energy accounts for 1972, 1975, 1976, and 1977. The estimate of total capacity drops sharply from 1972 to 1975. Since actual capacity did not drop, our assumption of a 60-percent 


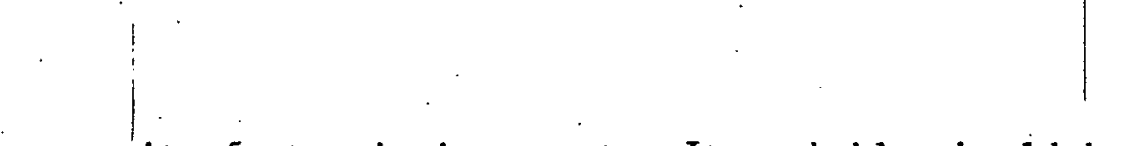

capacity factor is incorrect. It probably should be higher than 60 percent In 1972 and lower in 1975. Since a change in the average capacity factor changes the scale, but not the distribution of capacity and does not change any of the details of the process steam estimate, we shall retain a 60-percent capacity factor but warn the reader not to compare capacity estimates from different years.

The estimates of total process steam are the most important output of the calculation. They are a significant improvement over the estimates in the Phase I report (1).

Using the estimate of total process steam, we can define an average. power ratio by dividing the total production of electricity in Table A-1 by the total production of process steam. The average power ratio increases from $23.7 \mathrm{kWh}$ per 1000 pounds of process steam in 1972 to 27.4 in 1977.

A change in the relative number of full capacity hours for saturated bollers and superheated boilers changes the average power ratio in the model. To match the power ratio of 26.1 in 1975 requires equal capacity factors for both saturated and superheated bollers. To match the power ratio of 23.7 in 1972 requires a higher capacity factor for saturated bollers. To match the power ratto of 27.4 in 1977 requires a higher capacity factor for superheated boilers.

From 1972 to 1977 the fraction of the capacity that consumes spent 11quor and bark 1ncreased, whlle the fraction that consumes oil/gas decreased. The fraction of capacity in each type of throttle condition has remained almost constant. 
Using data from Table A-1 and the process steam estimates in Table A-14, we can develop the annual electricity and steam balance estimates shown in Table A-15. Based on discussions with API, we assume that energy sold is 70 percent electricity and 30 percent process steam.

The I-O coefficients for the boller options are shown in Table A-16. The source of the energy $I-0$ coefficlents is Table $A-12$. The sources of the materials, labor, and captal I- 0 coefficients are discussed in the notes for the table. Desplte the fact that the fuel costs for coal bollers are less than the fuel costs for ofl/gas bollers, both the operating costs and the total costs are greater for coal bollers than for ofl/gas bollers. In all cases higher throttle conditions result in lower operating costs and lower total cost. 
TABLE A-15. ANNUAL ELECTRICITY AND STEAM BALANCE FOR THE PAPERMILL INDUSTRY

Electricity $\left(10^{9} \mathrm{kWh} / \mathrm{yr}\right)$

Generated ${ }^{a}$

Purchased ${ }^{a}$

Sold b

Hydroa

Demand

$$
29.8167
$$

27.1458

$-2.9007$

2.5731

56.6349
28.1402

26.9483

$-3.5178$

2.6863

54.2570
31.6060

32.4624

$-3.8337$

2.8305

63.0652
33.4904

34.7852

$-3.7657$

2.8405

67.3504

Stean $\left(10^{9} 1 \mathrm{~b} / \mathrm{yr}\right)$

\section{Generated $c$ \\ Purchaseda \\ Sold ${ }^{b}$}

Demand

$$
\begin{array}{r}
1256.3226 \\
18.6673 \\
-3.5358
\end{array}
$$

1271.4541

$$
\begin{array}{r}
1078.7568 \\
13.6080 \\
-4.2880 \\
1088.0768
\end{array}
$$

$$
\begin{array}{r}
1183.0643 \\
15.2154 \\
-4.6731 \\
1193.6066
\end{array}
$$

1224.0970
16.9287
-4.5901
1236.4356

aSource: Table A-1.

bSource: Tabie A-1. Assumptions: Energy sold is 70 percent electricity and 30 percent steam, $1200 \mathrm{Btu} / \mathrm{lb}$ of steam, $3413 \mathrm{Btu} / \mathrm{kWh}$.

Cṣnurce: Tah1e A-14. 
TABLE A-16. INPUT-OUTPUT COEFFICIENTS FOR THE BOILER OPTIONS WHERE OUTPUT IS $10^{9}$ POUNDS OF PROCESS STEAM

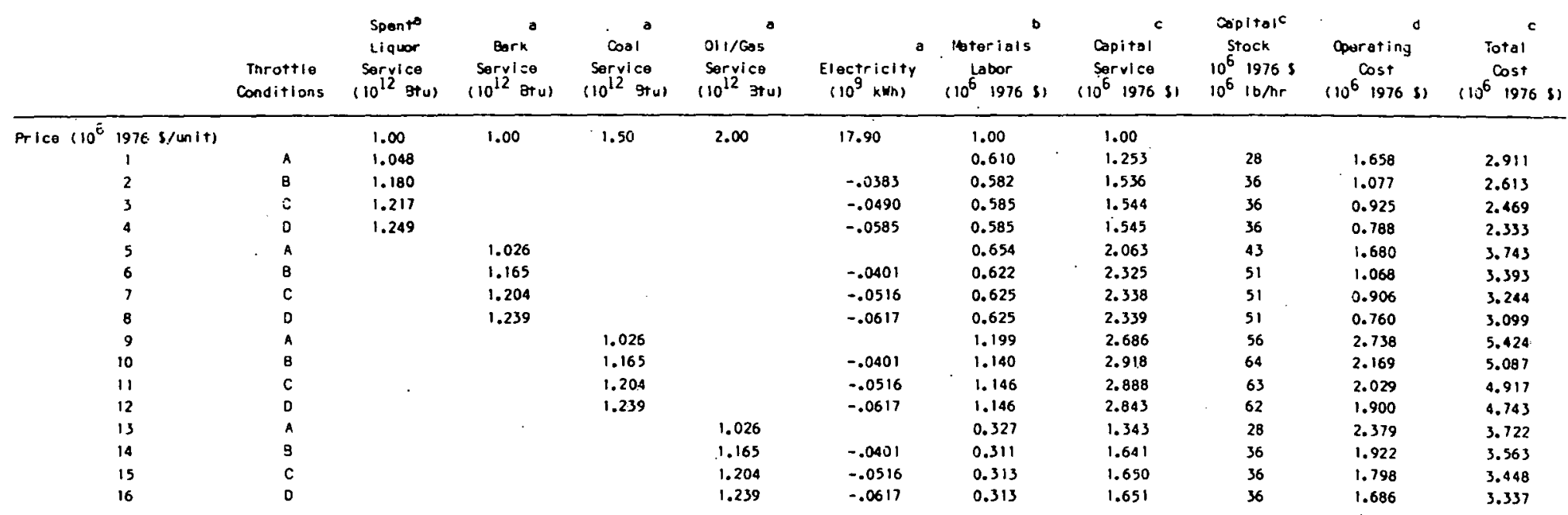

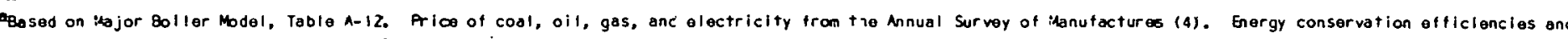
price of bark and spent ll quor are Cok zidge National Laboratory estimates.

Bosed on data trom EEA (5). The annual sperating cost for coal and oll/gas bollers aith a capacity of 100,000 10/hr are. 550,000 1936 $\mathrm{s}$ and $150,0001976 \mathrm{~s}$, respectively. aur estimate for a similar spent liquor or bari boller is $300,0001976 \mathrm{~s}$. Using data tran table A-13, a spent liquor bo ler with a capacity of 100,000 $1 \mathrm{~b} / \mathrm{hr}$ produces 0.492 billion pounds of process steam per pear. Thus, the operating cost for the boller is $300,000-0.492=610,00019.65$ per $10^{9}$ pounds of process steame. Similar calculations yiald the other est imates tor the operating (materials and lebor) cost.

cCapital zost estimates for bollers and generators trom (16) and (17). The price of copital is $228 / \mathrm{yr}$. The cost per bilulon pounds of process stam is determined by the

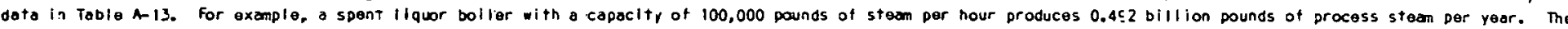
capital cost is 2.8 million dollars. At 228/yr the annual capital charge is 0.616 million dollars or 1.253 million dollars per billion pounds of process stesm.

The operating cast is the sum over all tactors except capital of price times the 1-0 scofficients.

Total sost is the sum of operating cost and the cost of capitat. 


\section{REFERENCES}

1. D. B. Relster, W. S. Chern, and H. D. Nguyen. 1979. "An EconomicEngineering Energy Demand Model for the Pulp and Paper Industry--Phase I Report," ORNL/CON-29. Oak Ridge National Laboratory, Oak Ridge, Tennessee.

2. D. B. Reister, R. W. Barnes, J. A. Edmonds, and B. Thomas. 1980. "The Oak Ridge Industrial Model," ORNL/CON-56. Oak Ridge National Laboratory, Oak Ridge, Tennessee.

3. J. R. Jackson and D. L. Kaserman. 1979. "A Neoclassical Theory of Durable Good Diffusion," ORNL/CON-37. Oak Ridge National Laboratory, Oak Ridge, Tennessee.

4. U.S. Bureau of the Census. 1973. "Fuels and Electric Energy Consumed," 1972 Census of Manufactures, Washington, D.C. U.S. Bureau of the Census. "Fuels and Electric Energy Consumed," Annual Survey of Manufactures 1974, 1975, and 1976. Three separate reports 1ssued in 1976,1977 , and 1978, respectively.

5. R. E. Bohn and J. S. Herod. 1978. "Industrial Sector Technology Use Model (ISTUM): Industrial Energy Use in the United States, 19742000," (draft report). Energy and Envilronmental Analysis, Inc., Arlington, Virginia.

6. E. G. Cazalet. 1977. "Generalized Equilibrium Modeling: The Methodology of the SRI-Gulf Energy Model," SRI International, Menlo Park, California.

7. Committee on Nuclear and Alternative Energy Systems (CONAES), National Research Council. 1979. Alternative Energy Demand Futures to 2010, report of the Demand and Conservation Panel, National Academy of Sciences, Washington, D.C., p. 49.

8. A. R. Major. 1977. "Energy Conservation In Power Plant Design for Pulp and Papermills," paper presented at the Mid-Winter Conference on Conservation and Resource Recovery for the Pulp and Paper Industry, Hilton Head Island, South Carolina.

9. R. H. Willams. 1978. "Industrial Cogeneration," Annual Review of Energy, Palo Alto, California.

10. American Paper Institute. 1978. "Estimated Fuel and Energy Use by the U.S. Pulp, Paper, and Paperboard Industry," (data sheet), New York, New York. 
11. American Boiler Manufacturers Association. 1978. "Stationary Water-. tube Boller Sales," Arlington, Virginia. The ABMA provided data to the Department of Energy, which has provided ORNL with the data. The ABMA data is summarized in C. L. Mason (12).

12. C. L. Mason. 1978. "Boiler Census in the Paper Industry Based on American Boller Manufacturers Association (ABMA) Sales Reports," Science Applications, Inc., Oak Ridge, Tennessee.

13. A Major Fuel Burning Installation (MFBI) is a factory that has one or more botlers or furnaces with a total design firing rate of 100 million Btu per hour or greater. In 1975 the Federal Energy Administration required all MFBI to complete an MFBI coal conversion report. The resulting MFBI data base has a substantial amount of information on the MFBI in the pajper Industry. The MFBI data base is confidential; ORNL has been allowed to use the data base under rigorous guide11nes that preserve confidentiality. The displays of MFBI data used in this report were prepared under the direction of $C$. L. Mason of SAI and are summarized in references 11 and 16.

14. D. L. Phung and H. Rohm. 1977. "A Unified Methodology for Cost Analysis of Energy Production," paper presented at the Mlami International Conference on Alternative Energy Sources, Miami Beach, Florida.

15. G. Samuels and P. E. Johnson. 1978. "A User's Review of the Major Fuel-Burning Installation Survey," ORNL/TM-6530, Oak Ridge National Laboratory, Oak Ridge, Tennessee.

16. C. L. Mason. 1978. "Engineering Analys1s Related to Development of an Energy Model for the Paper Industry," Science Applications, Inc., Oak Rldge, Tennessee.

17. Resource Planning Assoclates, Inc. 1977. "The Potential for Cogeneration Development In Six Major Industries by 1985," Cambridge, Massachuset ts. 
